\title{
Deglaciation and future stability of the Coats Land ice margin, Antarctica
}

\author{
Dominic A. Hodgson ${ }^{1,2}$, Kelly Hogan ${ }^{1}$, James M. Smith ${ }^{1}$, James A. Smith ${ }^{1}$, Claus-Dieter Hillenbrand ${ }^{1}$, Alastair G. \\ C. Graham ${ }^{3}$, Peter Fretwell ${ }^{1}$, Claire Allen ${ }^{1}$, Vicky Peck ${ }^{1}$, Jan-Erik Arndt ${ }^{4}$, Boris Dorschel ${ }^{4}$, Christian Hübscher ${ }^{5}$, \\ Andrew M. Smith ${ }^{1}$, and Robert Larter ${ }^{1}$ \\ ${ }^{1}$ British Antarctic Survey, High Cross, Madingley Road, Cambridge, CB3 0ET, UK \\ ${ }^{2}$ Department of Geography, University of Durham, Durham, DH1 3LE, UK \\ ${ }^{3}$ Department of Geography, University of Exeter, Exeter, EX4 4RJ, UK \\ ${ }^{4}$ Alfred Wegener Institute Van-Ronzelen-Str. 2, 27568 Bremerhaven, Germany \\ ${ }^{5}$ Institute of Geophysics, University of Hamburg, Bundesstr. 5520146 Hamburg, Germany
}

Correspondence: Dominic A. Hodgson (daho@bas.ac.uk)

Received: 11 January 2018 - Discussion started: 6 March 2018

Revised: 14 May 2018 - Accepted: 18 May 2018 - Published: 20 July 2018

\begin{abstract}
The East Antarctic Ice Sheet discharges into the Weddell Sea via the Coats Land ice margin. We have used geophysical data to determine the changing ice-sheet configuration in this region through its last glacial advance and Holocene retreat and to identify constraints on its future stability. Methods included high-resolution multibeam bathymetry, sub-bottom profiles, seismic-reflection profiles, sediment core analysis and satellite altimetry. These provide evidence that Coats Land glaciers and ice streams merged with the palaeo-Filchner Ice Stream during the last glacial advance. Retreat of this ice stream from 12848 to 8351 cal. yr BP resulted in its progressive southwards decoupling from Coats Land outlet glaciers. Moraines and grounding-zone wedges document the subsequent retreat and thinning of these glaciers, their loss of contact with the bed and the formation of ice shelves, which re-advanced to pinning points on topographic highs at the distal end of the troughs. Once fully detached from the bed, these ice shelves were predisposed to rapid retreat back to coastal grounding lines. This was due to reverse-bed slopes, the consequent absence of further pinning points in the troughs and potentially to the loss of structural integrity resulting from weaknesses inherited at the grounding line. These processes explain why there are no large ice shelves in the eastern Weddell Sea between 75.5 and $77^{\circ} \mathrm{S}$.
\end{abstract}

\section{Introduction}

The Weddell Sea captures the drainage of about one-fifth of Antarctica's present-day continental ice volume. Recent studies of the submarine and subglacial topography of the Weddell Sea have revealed features in the geometry of the ice and bed that make the West Antarctic Ice Sheet (WAIS) catchments prone to grounding line instability and ice-sheet drawdown. These include (i) grounding depths of about 1000 to $>1200 \mathrm{~m}$ below sea level on a bed with locally reversed slopes, (ii) ice close to floatation inland of the grounding line and (iii) a large subglacial basin upstream of the present-day grounding line (e.g. BEDMAP 2, Fretwell et al., 2013; Ross et al., 2012).

Less well known is the configuration and geometry of the East Antarctic Ice Sheet (EAIS) catchments draining into the Weddell Sea, some of which also have ice streams with subglacial basins upstream of the grounding line (e.g. Bamber et al., 2006; Rippin et al., 2006). Understanding these catchments is important because uncertainties remain about the Last Glacial Maximum (LGM) ice extent, the timing and nature of deglaciation through Termination 1 and the Holocene and the key processes determining the present configuration and future stability of the EAIS in this region. There are currently three main data sources. First, field data on icesheet history based on glacial geomorphology and cosmogenic isotopes in the interior mountains (Pensacola Mountains and Shackleton Range; Fig. 1a, c) show only a mi- 


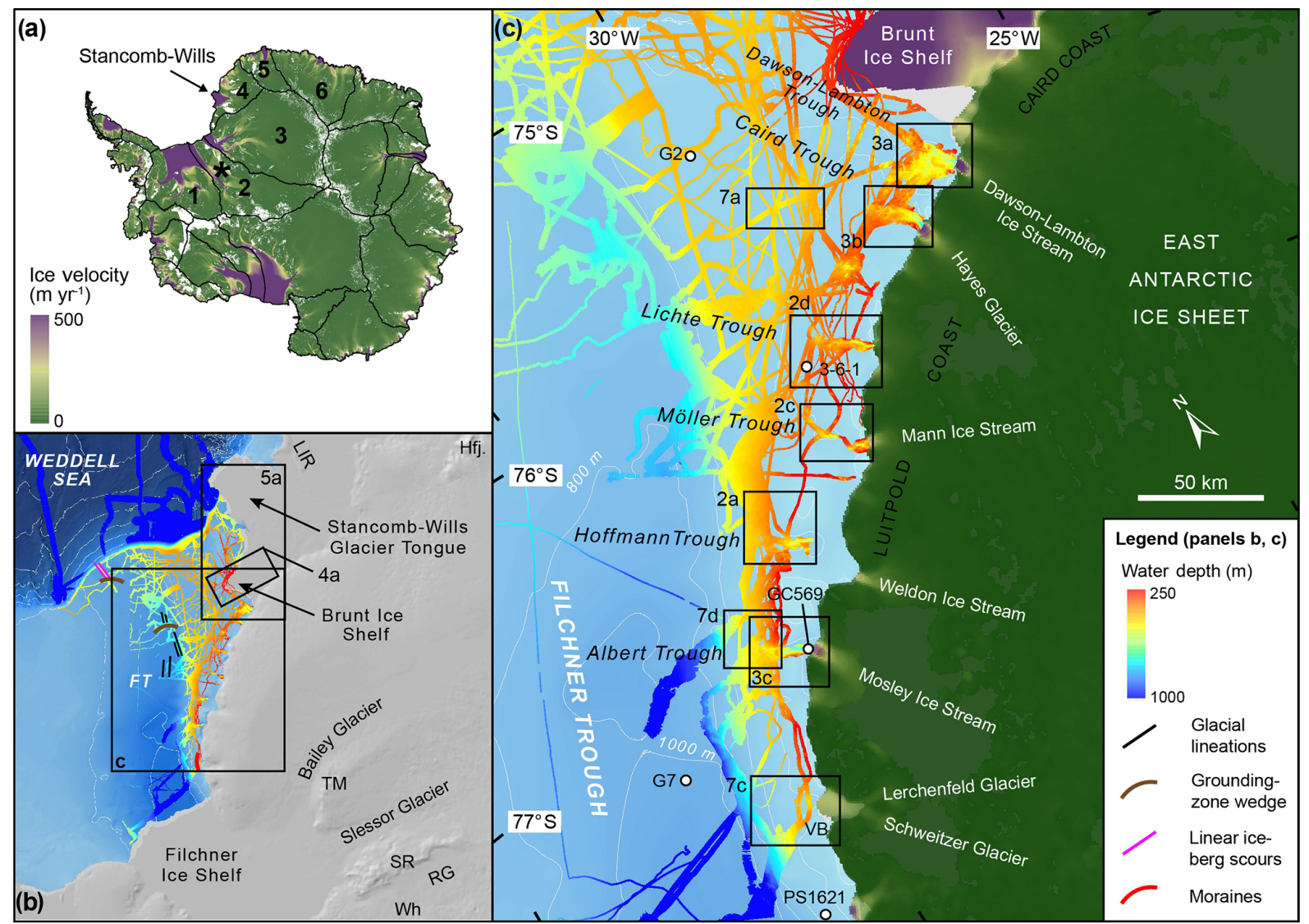

Figure 1. Location maps of the Coats Land ice margin, East Antarctica. (a) Map of Antarctica with ICESat-derived drainage basins (http: //icesat4.gsfc.nasa.gov/cryo_data/ant_grn_drainage_systems.php, last access: 2017) and MEaSUREs ice velocities (Rignot et al., 2011). The study area is the south-western part of Antarctic Drainage System 4. To the south of the study area, Antarctic Drainage System 3 discharges into the Thiel Trough and Filchner Ice Shelf via the Bailey Ice Stream, Slessor, Recovery and Support Force glaciers. To the north Antarctic Drainage Systems 5 and 6 discharge into the ice shelves of Dronning Maud Land. The black star is the Penascola Mountains. (b) The continental shelf and glaciology of the eastern Weddell Sea showing the multibeam-bathymetry coverage (for survey details see text); regional bathymetry is from IBCSO v. 1.0; Arndt et al. (2013). Hfj. is Heimefrontfjella; TM is Theron Mountains; SR is Shackleton Range; RG is Recovery Glacier; Wh is Whichaway Nunataks; LIR is Lyddan Ice Rise. Also shown is the location of offshore glacial landforms described in Larter et al. (2012) and Arndt et al. (2017). Labelled boxes show the locations of Figs. 1c, 4a and 5a. (c) Detailed map showing multibeam-bathymetry coverage in glacial troughs of the Coats Land ice margin and eastern Weddell Sea and the MEaSUREs ice velocities of regional glaciers and ice streams. The location of datasets shown in Figs. 2, 3 and 7 is marked by labelled boxes. Labelled white circles with a black borders show the locations of sediment coring sites referred to in the text and Table 1. VB is Vahsel Bay.

nor thickening or no change in the ice-sheet thickness at the LGM (Bentley et al., 2010; Hein et al., 2011; Hodgson et al., 2012). Linked to this, some models of the ice-loading history (Whitehouse et al., 2012a) show subsidence in the western EAIS driven by a prediction of lower accumulation rates during the glacial period (Parrenin et al., 2004) and a gradual thickening after the LGM. Data from further north (Heimefrontfjella; Fig. 1b) have been used to support the latter (Hättestrand and Johansen, 2005), but the evidence remains undated. Second, modelling of palaeo-ice thicknesses in Coats Land based on ice core data suggests initial thinning from the LGM followed by re-thickening over the last $5 \mathrm{ka}$ (Huybrechts et al., 2007). Third, marine geological data suggest a major advance of grounded ice from Coats Land towards the continental shelf break in the Weddell Sea; however, there is limited empirical evidence on the timing and nature of this advance and its subsequent retreat (Hillenbrand et al., 2014, 2012).

It is clear, therefore, that there are insufficient data to underpin robust assessments of mass balance changes on millennial timescales over this significant region of Antarctica. As a result, estimates of the sea-level equivalent volume of LGM ice build-up in the Weddell Sea range from 1.4 to $3 \mathrm{~m}$ (Le Brocq et al., 2011) up to a maximum of $13.1 \mathrm{~m}$ (Bassett et al., 2007), with the contribution from the palaeoFilchner Ice Stream (pFIS) possibly being as little as 0.05 to $0.13 \mathrm{~m}$ (Whitehouse et al., 2017). This wide range of uncertainty limits the accuracy of modelled estimates of sea- 
level contributions from the Weddell Sea ice catchments, which is being addressed by a range of studies. These include developing new constraints on glacio-isostatic adjustment based on GPS measurements of uplift and horizontal motion (Whitehouse et al., 2012b), studies of the ice-sheet history in interior mountain ranges and nunataks (e.g. Heimefrontfjella, Theron Mountains, Shackleton Range and Whichaway Nunataks; Fig. 1c) based on cosmogenic isotope analyses of glacially deposited material (e.g. Hein et al., 2014), radiocarbon ages on organic deposits that record ice absence (e.g. Thor and Low, 2010) and studies of the ice sheet where it discharges into the Weddell Sea. This paper addresses the last of these by studying the submarine geomorphology of the main glacial outlets of Coats Land (Fig. 1). Our aims were (i) to understand the nature and timing of the LGM ice advance from Coats Land and how it interacted with the pFIS occupying the Filchner Trough; (ii) to identify how and when the ice retreated; (iii) to describe the physical constraints on the stability of the current ice margin based on its submarine geomorphology and ice-sheet geometry and account for the absence of ice shelves south of $75.5^{\circ}$; and (iv) to assess how these will influence the future stability of the ice margin, including its largest extant ice-shelf system consisting of the Brunt Ice Shelf (BIS) and Stancomb-Wills Glacier Tongue (SWGT) (Fig. 1).

\section{Site description}

The study area is the south-western part of Antarctic Drainage System 4 (as defined by Zwally et al., 2012) (Fig. 1a). Here, the EAIS discharges into the Weddell Sea via the Coats Land ice margin: $600 \mathrm{~km}$ of marine-terminating glaciers, glacier tongues and ice shelves along the Luitpold and Caird coasts between the Filchner and RiiserLarsen ice shelves from 74 to $77^{\circ} \mathrm{S}$. From north to south the main glaciers include the Stancomb-Wills Glacier, Dawson Lambton Ice Stream, Hayes Glacier, "Lichte Glacier", Mann Ice Stream, Weldon Ice Stream, Mosley Ice Stream and the Lerchenfeld and Schweitzer glaciers. These discharge into the Brunt Basin, Dawson-Lambton, Caird, Lichte, Möller, "Hoffmann" and Albert troughs, and an unnamed trough in Vahsel Bay, respectively (quotation marks denote unofficial names). The Stancomb-Wills Glacier and Dawson Lambton Ice Stream form glacier tongues extending 250 and $20 \mathrm{~km}$ from their grounding lines, respectively. Ice shelves include the BIS, which is formed from a series of unnamed glaciers extending from the grounding line and is pinned to the bed at McDonald Ice Rumples $\left(75^{\circ} 28^{\prime} \mathrm{S}, 26^{\circ} 18^{\prime} \mathrm{W}\right)$. Together with the SWGT, it forms a continuous floating ice mass with a number of large cracks and chasms and a melange of icebergs and sea ice where it forms at the grounding line (Anderson et al., 2014). At the southern limit of the study area the Lerchenfeld and Schweitzer glaciers feed a small $(30 \mathrm{~km}$ long, 10-20 km wide) ice shelf maintained through lateral buttressing in Vahsel Bay (Fig. 1b).

\section{Methods}

Multibeam-bathymetric surveys of accessible troughs were carried out on the RRS James Clark Ross cruise JR244 in February-March 2011 and combined with data from JR97 in February-March 2005 and JR259 in February-March 2012. These surveys include the bathymetry presented in Figs. 2, 3, 4 and $7 \mathrm{~d}$ and multiple ship tracks along the margins of Filchner Trough and BIS. The data were acquired with a hull-mounted Kongsberg-Simrad EM 120 multibeam echo sounder operated in a $1^{\circ} \times 1^{\circ}$ configuration, emitting 191 beams at a frequency of $11.25-12.75 \mathrm{kHz}$. The system acquires data at a resolution that allows for gridding with cell sizes of $10-70 \mathrm{~m}$, dependent on water depth. Port and starboard beam angles were typically $68^{\circ}$, resulting in a swath width of up to 5 times water depth. Additional multibeam data were acquired by the RV Polarstern using Hydrosweep DS1 (expeditions ANT-VIII/5 (1989/90), ANT-IX/3 (1991), ANT-X/2 (1992) and ANT-XII/3 (1995)), DS2 (ANT-XVI/2 (1999)), DS3 (PS82 (2013/14)) and PS96 (2015/16) systems. These surveys include the bathymetry presented in Fig. 7a and $c$ and ship tracks in the eastern Weddell Sea. These data were processed in CARIS HIPS/SIPS. The EM 120 multibeam data were ping-edited in the UNIX-based MB System $^{\mathrm{TM}}$ (http://www.mbari.org/data/mbsystem, last access: 2017) and all datasets were gridded together using MB System and QPS Fledermaus. Final gridded datasets were produced with cell sizes ranging from 35 to $40 \mathrm{~m}$. This ensured that the highest-resolution grid was obtained whilst ensuring that each cell included multiple seafloor soundings. Minimal interpolation of the grids was then performed to fill small holes (up to 6 grid cells in one direction) in the data. Visualisation and morphological analyses were carried out in QPS Fledermaus and ArcGIS software.

The multibeam data were supplemented with regional bathymetry from the International Bathymetric Chart of the Southern Ocean (IBSCO; Arndt et al., 2013). In the region of the BIS and SWGT a new $500 \mathrm{~m}$ regional grid was produced from all available sea floor depth data. This included (i) pixels from IBSCO that directly overlaid source data, including single-beam echo sounder depth surveys; (ii) depth measurements from historical ship tracks inland of the present iceshelf front, currently at its most advanced position since at least 1958 and probably since 1915 (Anderson et al., 2014); (iii) pixels from BEDMAP2 (Fretwell et al., 2013) that overlaid source data inland of the grounding line; and (iv) 38 unpublished BAS seismic soundings acquired in 2004 from the surface of the BIS-SWGT. Several assumptions of ice density were made to convert these seismic soundings to depths; the top $30 \mathrm{~m}$ of ice was assumed to be a firn layer with a mean density of $750 \mathrm{~kg} \mathrm{~m}^{-3}$, giving a seismic velocity of $3.2 \mathrm{~km} \mathrm{~s}^{-1}$. Below this the ice was treated as a solid with a seismic velocity of $3.7 \mathrm{~km} \mathrm{~s}^{-1}$. The seawater cavity was modelled with a seismic velocity of $1455 \mathrm{~m} \mathrm{~s}^{-1}$ based on a mean depth of $600 \mathrm{~m}$, salinity of $35 \mathrm{ppt}$ and temperature of 

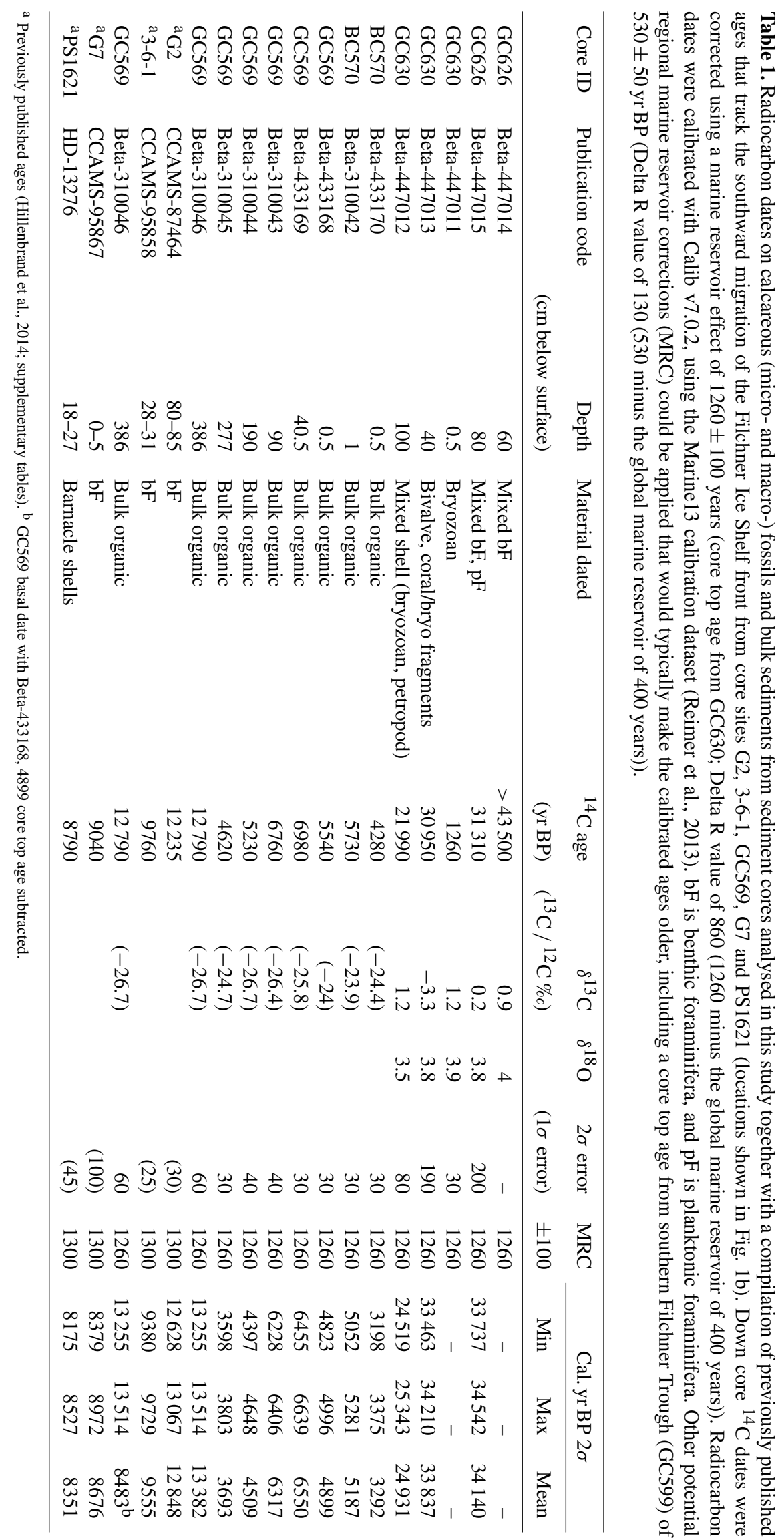
$-1{ }^{\circ} \mathrm{C}$. The seismic soundings were acquired with a $400 \mathrm{~m}$ 12-geophone cable with take-outs every $30 \mathrm{~m}$, connected to a Bison seismograph. Standard seismic high-explosive $200 \mathrm{~g}$ charges were initiated by electric detonators. The network of 47 seismic data points were screened for interference from the internal structure of the ice shelf with 9 outliers discarded from the analysis. Point datasets were combined and then regridded using the "Topo to Raster" tool in ArcGIS, with an output cell size of $500 \mathrm{~m}$.

Seafloor sediments were investigated using sub-bottom profiles along the long axes of the surveyed glacial troughs, one seismic-reflection profile and multiple sediment cores.

Sub-bottom profiles were acquired on RRS James Clark Ross with a hull-mounted Kongsberg Simrad TOPAS PS018 sub-bottom parametric echo sounder with secondary chirp pulse frequencies between 1.3 and $5 \mathrm{kHz}$.

Seismic data were acquired on the same vessel using a high-resolution air gun seismic-reflection profiling system consisting of a single GI gun, firing in true GI mode with generator and injector volumes of 45 and 105 in. ${ }^{3}$, respectively, producing a signal of $100 \mathrm{~Hz}$ dominant frequency. A 16channel streamer with a channel spacing of $6.25 \mathrm{~m}$, with an active section of $100 \mathrm{~m}$, was used for recording the data. Data processing included frequency filtering $(15-350 \mathrm{~Hz})$, gain, velocity analysis (every $50 \mathrm{CMPs}$ ), NMO correction, coherency filtering, stacking, time migration, bandpass, white noise removal, dip filtering and FX deconvolution as described in Hübscher and Gohl (2014).

To determine the nature of the bed and the sedimentological record of glaciation, sediment cores were collected with a combination of a 3-12 m $\times 110 \mathrm{~mm}$ gravity corer (P. Smit, Netherlands) and a $300 \mathrm{~mm}$ square box corer (Duncan \& Associates). Cores were split and described at the British Antarctic Survey, UK, following standard methods (Smith et al., 2011). Shear strength was measured on the split cores using a handheld shear vane. Sediment slices of $1 \mathrm{~cm}$ were weighed, dried and used to calculate water content. Dried samples were then disaggregated and passed through $2 \mathrm{~mm}$ and $63 \mu \mathrm{m}$ sieves to obtain gravel, sand and mud fractions. To establish a chronology, calcareous (micro-)fossils were picked from the $63 \mu \mathrm{m}$ to $2 \mathrm{~mm}$ fraction and, if sufficient in volume, were submitted for ${ }^{14} \mathrm{C}$ dating at Beta Analytic, USA. Where microfossils were absent the acid-insoluble organic fraction was dated. Dates were calibrated with Calib v7.0.2, utilising the Marine13 calibration dataset (Reimer et al., 2013) and a marine reservoir effect of $1260 \pm 100$ years, (core top age from GC630; Delta R of 860 (1260 minus the global marine reservoir of 400). Other reservoir ages or surface corrections have also been applied in this region (e.g. Hillenbrand et al., 2014, 2012; Stolldorf et al., 2012), Table 1 .

Interactions between ice shelves and the bed were studied using ICESat surface altimetry (Zwally et al., 2012). All geophysical data are archived in the NERC UK Polar Data
Centre (https://www.bas.ac.uk/data/uk-pdc/, last access: 18 July 2018).

\section{Results}

Ice from Coats Land discharges into the Weddell Sea via a series of glaciers and ice streams with velocities ranging from less than 100 to over $500 \mathrm{~m} \mathrm{yr}^{-1}$ (Fig. 1c). These glaciers terminate in a series of deeply incised $\mathrm{W}$ - to $\mathrm{WNW}$-oriented glacial troughs, approximately $50 \mathrm{~km}$ apart and extending up to $40 \mathrm{~km}$ from the present ice margin towards the Filchner Trough. The troughs share a number of common glacial geomorphological features including marked reverse-bed slopes, over-deepened basins, moraine complexes, streamlined landforms and grounding-zone wedges (GZWs), described below.

\subsection{Glacial troughs with reverse-bed slopes, over-deepened basins and sediment infills}

All surveyed glacial troughs were characterised by reversebed slopes ranging from moderate (e.g. Möller Trough, which deepens by $100 \mathrm{~m}$ along a $34 \mathrm{~km}$ profile; Fig. 2c, e) to steep (e.g. Albert Trough, which deepens by $450 \mathrm{~m}$ along a $26 \mathrm{~km}$ profile; Fig. 3c, d).

Over-deepened basins are present in all troughs with the deepest basins being at the eastern limits of the surveys, closest to the modern ice front. In some cases, large, deep basins were observed extending under the modern ice front, for example in the Caird and Albert troughs (e.g. Fig. 3b, c). In other cases, such as the Hoffman, Möller, Lichte and SWGT troughs, there are a series of two or more deep basins becoming progressively more poorly defined with increasing distance from the modern ice front (Figs. 2, 5). Some of the deep basins have 20 to $60 \mathrm{~m}$ high moraines on their seaward side, for example in Caird and Albert troughs (Fig. 3b, c, e). Other deep basins are separated by bedrock sills, for example in Dawson-Lambton Trough, where the deep basins have complex morphologies that appear to be bedrock controlled (Fig. 3a).

The volume of sediment infilling in the troughs and deep basins is variable with troughs downstream of the lowervelocity glaciers $\left(<250 \mathrm{~m} \mathrm{yr}^{-1}\right.$; Fig. 1b) typically characterised by ice-moulded bedrock and low volumes of sediment (e.g. Hoffmann, Möller and Lichte troughs; Fig. 2a-c). This was confirmed by gravity and box cores, which only recovered $18 \mathrm{~cm}$ of diamicton overlain by $40 \mathrm{~cm}$ of diatomaceous ooze in Möller Trough (BC608, Fig. 2c) and $47 \mathrm{~cm}$ of sediments in Lichte Trough (GC613, Fig. 2d), or did not recover any sediments (box core BC606 and gravity cores GC609 and GC610; Fig. 2c). In contrast, troughs downstream of higher-velocity glaciers $\left(>250 \mathrm{~m} \mathrm{yr}^{-1}\right)$, including the Albert and Dawson-Lambton troughs (Fig. 3a-c) and the Brunt Basin (Figs. 4, 5), contain high volumes of sediments. In Al- 

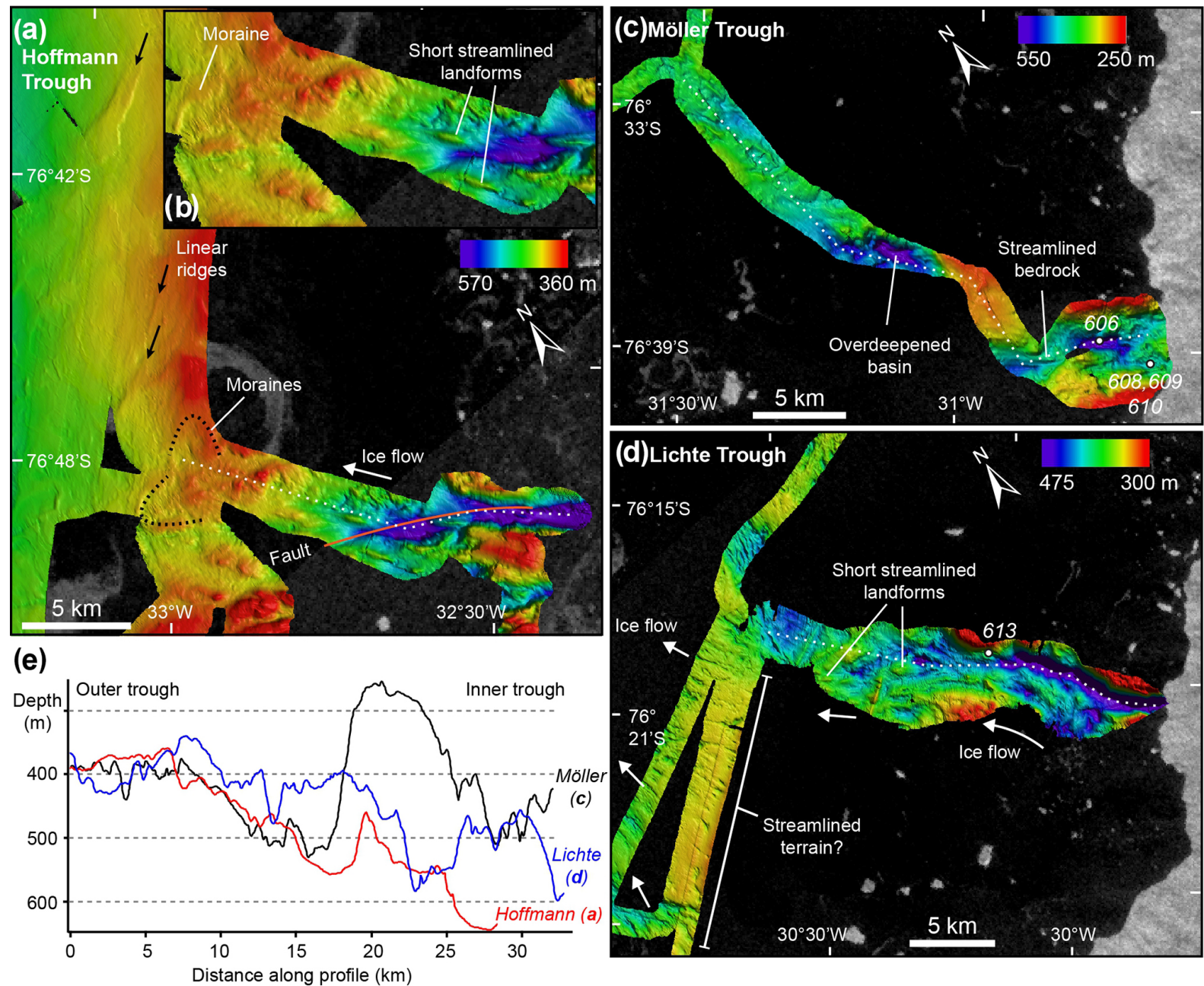

Figure 2. Geomorphology of glacial troughs downstream of low-velocity glaciers $\left(<250 \mathrm{~m} \mathrm{yr}^{-1}\right)$ : (a, b) Hoffmann Trough, (c) Möller Trough and (d) Lichte Trough, with labelled examples of streamlined landforms, moraines and bedrock terrain. Sediment core locations are marked by white circles with associated core numbers. Background image is an Envisat synthetic aperture radar image from 21 February 2011 to show the position of the ice front during the survey (cruise JR244). (e) Long profiles down the central axis of the troughs showing rugged but generally landward-dipping geometries; profile locations are marked with white dotted lines in panels (a), (c) and (d).

bert Trough a sediment drape is present in the $900 \mathrm{~m}$ deep inner basin. A box core from this basin (BC566; Fig. 3c) consists of a gravelly mud unit overlain by a diatomaceous ooze with abundant dropstones. A similar sequence was found in a $4.08 \mathrm{~m}$ long gravity core (GC569; see Fig. 3c for location, Fig. 6 for core log) which included a glacial deposit of stiff, greenish-grey gravelly mud and clasts below $3.88 \mathrm{~m}$ overlain by laminated diatomaceous muds and oozes with occasional sand layers.

\subsection{Moraines and moraine complexes}

Arcuate ridges of several kilometres in length and up to $35 \mathrm{~m}$ in height are present in Hoffmann, Albert and Caird troughs (Figs. 2a, 3b, c). These ridges are transverse to the long axis of the troughs, typically symmetric and steep- sided in cross profile (Fig. 3e). There is no acoustic penetration of these features on sub-bottom profiles, suggesting that they consist of coarse, diamictic and/or compacted material. The most extensive ridges occur at the western end of the trough basins (e.g. Hoffmann, Albert and the Lerchenfeld/Schweitzer glacier troughs; Figs. 2a, 3c, 7c). The dimensions, morphologies and locations of these ridges, transverse to the former ice-flow direction, indicate that they represent terminal push moraines formed during an advance or readvance of grounded ice in the troughs (e.g. Ottesen et al., 2005). The smaller ridges found at topographic highs and/or narrow trough sections between trough basins (e.g. Hoffmann and Caird troughs; Figs. 2a, 3b) most likely represent recessional moraines formed during minor still stands of the retreating grounding line. 

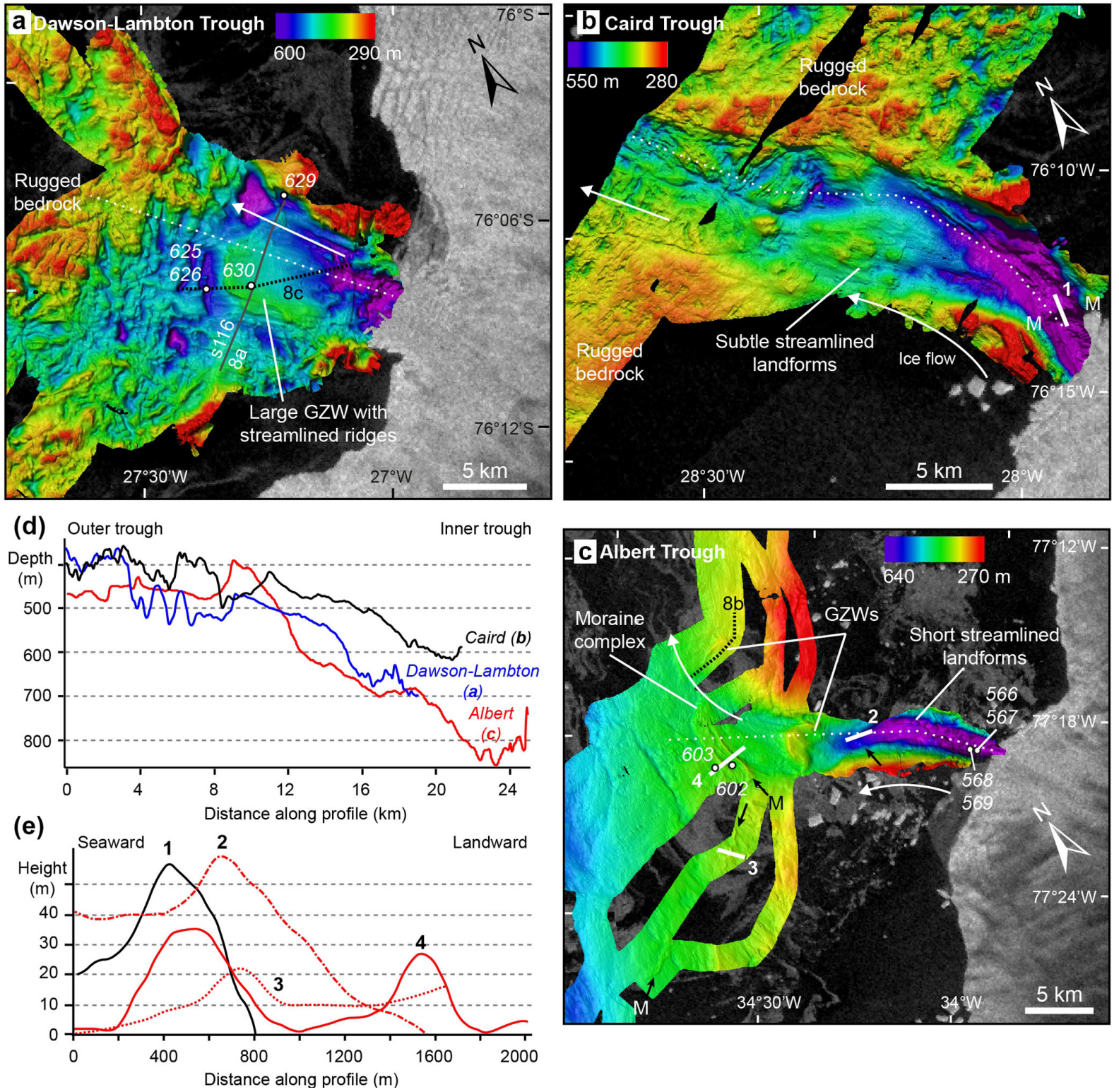

Figure 3. Geomorphology of glacial troughs downstream of high-velocity glaciers $\left(250-500 \mathrm{~m} \mathrm{yr}^{-1}\right)$. Background image is an Envisat synthetic aperture radar image from 21 February 2011 to show the position of the ice front during the survey (cruise JR244). (a) DawsonLambton Trough, black line shows the location of seismic-reflection profile BAS101-s116 along the strike of the large grounding-zone wedge (GZW, shown in Fig 8a), (b) Caird Trough and (c) Albert Trough, with labelled examples of streamlined landforms, moraines (arrowed and labelled "M") and GZWs. (d) Long profiles down the central axis of the troughs showing landward-dipping geometries; profile locations are marked with white dotted lines in panels (a), (b) and (c). (e) Cross profiles over prominent ridge features interpreted as moraines; profile locations are marked with solid white lines in panels (b) and (c). Sediment core locations are marked by white circles with associated core numbers.

\subsection{Streamlined landforms}

A variety of elongate streamlined landforms also occur in the troughs. These range from long, low amplitude, straight ridges, to arcuate ridges separated by depressions (e.g. Dawson-Lambton and Albert troughs; Fig. 3a, c); dimensions are $1-3 \mathrm{~km}$ in length, $5-10 \mathrm{~m}$ in height and $200-500 \mathrm{~m}$ in width with elongation ratios of up to $10: 1$. The subdued morphology of the ridges and rare sub-bottom reflections in TOPAS profiles indicate that they consist of unlithified sediments. We interpret these trough-parallel landforms as subglacial lineations formed by fast glacier flow over a deformable bed (see King et al., 2009; Ó Cofaigh et al., 2005). Shorter streamlined landforms consist of rounded to bluntnosed hills with a tapered (seaward) end up to $70 \mathrm{~m}$ high and 


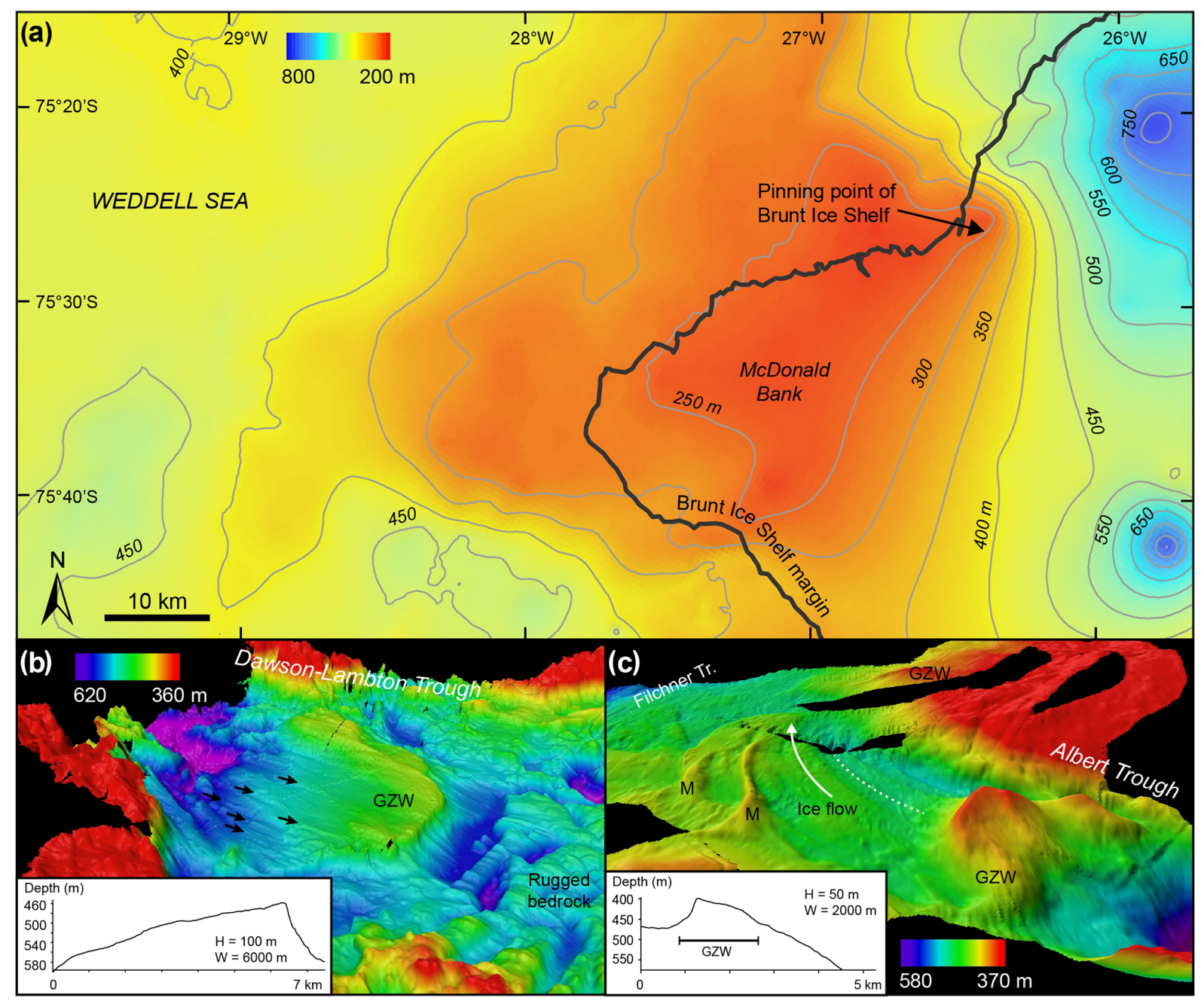

Figure 4. (a) Bathymetry of the McDonald Bank, a topographic high that rises to $\sim 220 \mathrm{~m}$ (water depth) under the Brunt Ice Shelf between the Brunt Basin and the Filchner Trough in the eastern Weddell Sea. The south-east part of the McDonald Bank consists of a ca. $75 \mathrm{~m}$ high ridge of sediments with internal truncated reflections (seismic profile 5; Elverhøi and Maisey, 1983). At its highest point, this ridge makes contact with the Brunt Ice Shelf forming the McDonald Ice Rumples. Three-dimensional images of grounding-zone wedges (GZWs) in (b) Dawson-Lambton Trough and (c) Albert Trough. Black arrows in (b) point to glacial lineations; insets show cross profiles of the GZWs.

$1.8 \mathrm{~km}$ long (elongation ratios $<5: 1$ ), usually in the inner and middle parts of the troughs (Figs. 2d, 3c). Sub-bottom profiles do not show penetration through acoustic basement, indicating that these features are likely formed in bedrock. These landforms are interpreted as subglacially moulded rôche moutonnée, whaleback forms and small crag and tails (see Livingstone et al., 2015; Nitsche et al., 2013). In Albert Trough, glacial lineations extend throughout the trough and curve northwards, where the trough widens into the Weddell Sea Embayment (Figs. 4c, 7d), suggesting that past ice flow was deflected northwards where the Albert Glacier joined the pFIS in Filchner Trough.

\subsection{Grounding-zone wedges and topographic highs}

Relatively wide (2-40 km), subdued, asymmetric ridges and topographic highs occur offshore of the Caird and Albert troughs (Fig. 7) and inshore within the Dawson-Lambton and Albert troughs (Fig. 4b, c). These features are up to $100 \mathrm{~m}$ high and have the steep seaward-facing slopes and gentler landward slopes typical of GZWs (Dowdeswell and Fugelli, 2012; Graham et al., 2009). These typically form at the grounding line of a retreating ice mass when it pauses for periods of several decades up to a few thousand years (Alley et al., 1989; Dowdeswell and Fugelli, 2012). The widest GZWs or recessional moraines are found $>20 \mathrm{~km}$ north-west of Caird Trough, marking a series of at least five grounding line positions (Fig. 7a). There are similar GZWs, marking at 


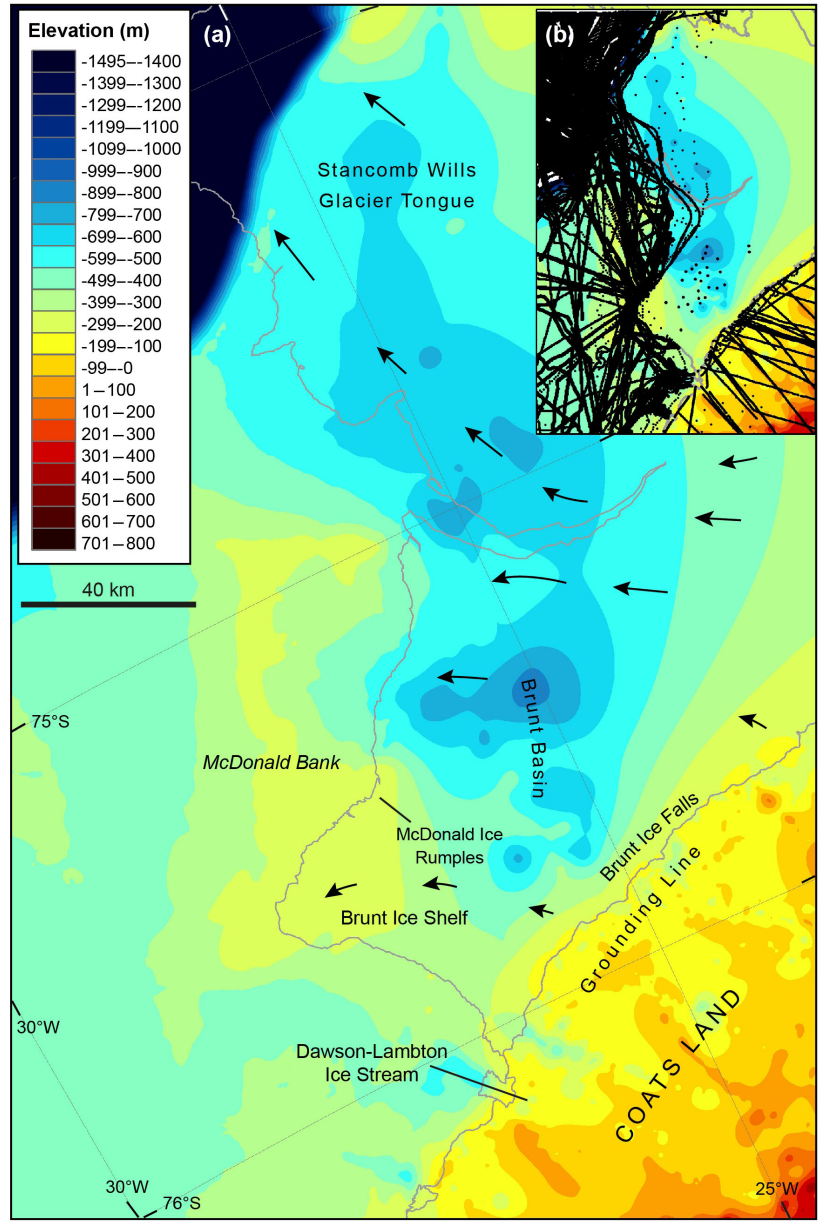

Figure 5. (a) Submarine geomorphology under the Brunt Ice Shelf and Stancomb-Wills Glacier Tongue (BIS-SWGT) showing that the Brunt Basin consists of a NNW-oriented glacial trough beneath the BIS and SWGT, separated from the Filchner Trough by the McDonald Bank. This image was compiled from multiple data sources, including multibeam and single beam bathymetric data incorporating historical ship tracks inland of the present ice-shelf front, the International Bathymetric Chart of the Southern Ocean data (IBSCO; Arndt et al., 2013) and seismic surveys of the depth to the seabed from the surface of the BIS-SWGT. Black arrows depict contemporary ice-flow directions. (b) Data density including locations of ship tracks (solid black lines offshore), historical depth soundings (dots on the SWGT) radar surveys (solid back lines over the inland ice) and ice-shelf seismic survey points (dots on the BIS).

least three grounding line positions north of Albert Trough (Figs. 4c, 7d), the northernmost two of which (Figs. 7d, 1 and 2) are oriented transverse to past ice flow in Filchner Trough (Fig. 7d, red arrow).

The GZW within the Dawson-Lambton Trough was studied in detail. Its gently dipping upstream side $\left(\sim 1^{\circ}\right)$ and much steeper downstream side $\left(7-9^{\circ}\right)$ (Fig. 4b) indicate that it was deposited by a seaward-thinning glacier, and the presence of lineations and notable absence of plough

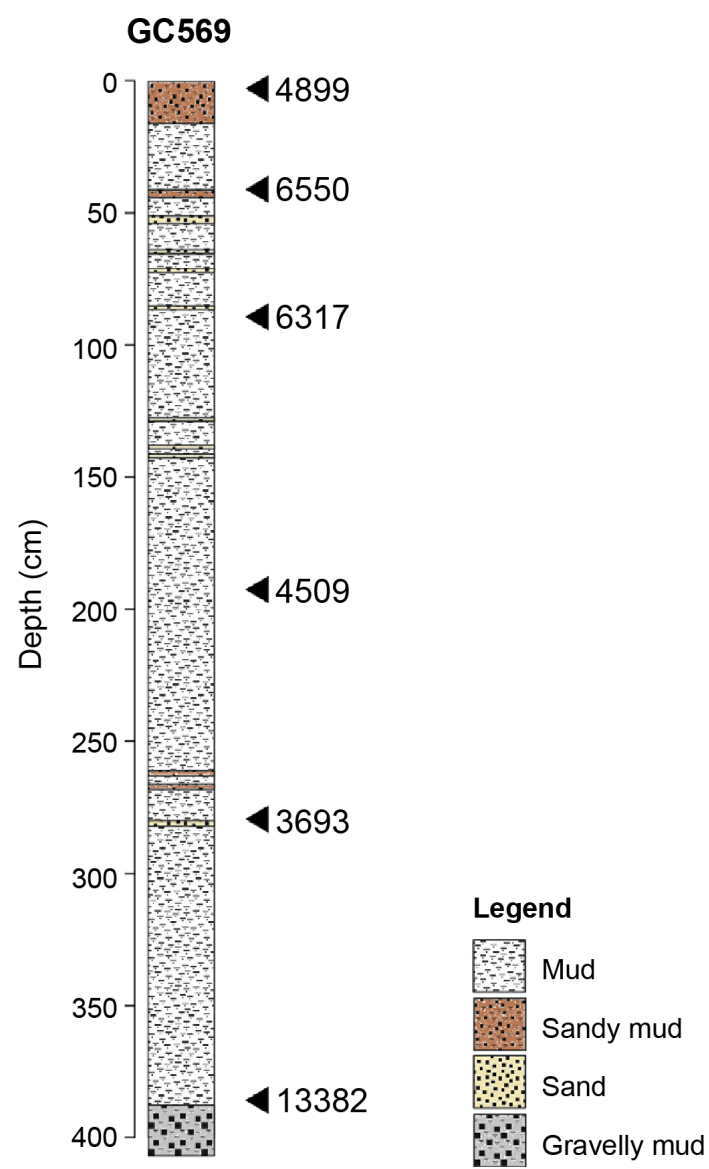

Figure 6. Sediment core log for GC569, a $4.08 \mathrm{~m}$ long gravity core from the deep basin in Albert Trough (see Fig. 3c for location). The core consists of stiff, greenish-grey gravelly mud and clasts below $3.88 \mathrm{~m}$, overlain by laminated diatomaceous muds and oozes with occasional sand layers. The latter indicate open water marine sedimentation over the site or possibly advection of nearby diatom blooms under an ice shelf.

marks suggest that ice was fast flowing and probably already near to floatation (see Batchelor and Dowdeswell, 2015). An along-strike seismic profile shows multiple architectural units. These include dipping reflections in a bank at the western side of the wedge consistent with development through lateral progradation. Along-trough progradation can be inferred from the top sets and discrete units in the internal architecture of the GZW (Fig. 8a). The base of a sediment core recovered from the crest of the GZW (GC630, Fig. 9a) consists of a sandy mud containing large clasts, calcareous marine micro-fossils. Its low water content and high shear strength are consistent with glaciomarine sediments. This is overlain by a thin layer of structureless diamicton, interpreted as a subglacial till formed by grounded ice. The upper unit of the core consists of gravelly sands and sandy muds. A second core on the seaward side of the GZW (GC626, Fig. 9b) is characterised by a sequence of sandy mud and normally graded gravel to muddy sand, interpreted as debris flows, 

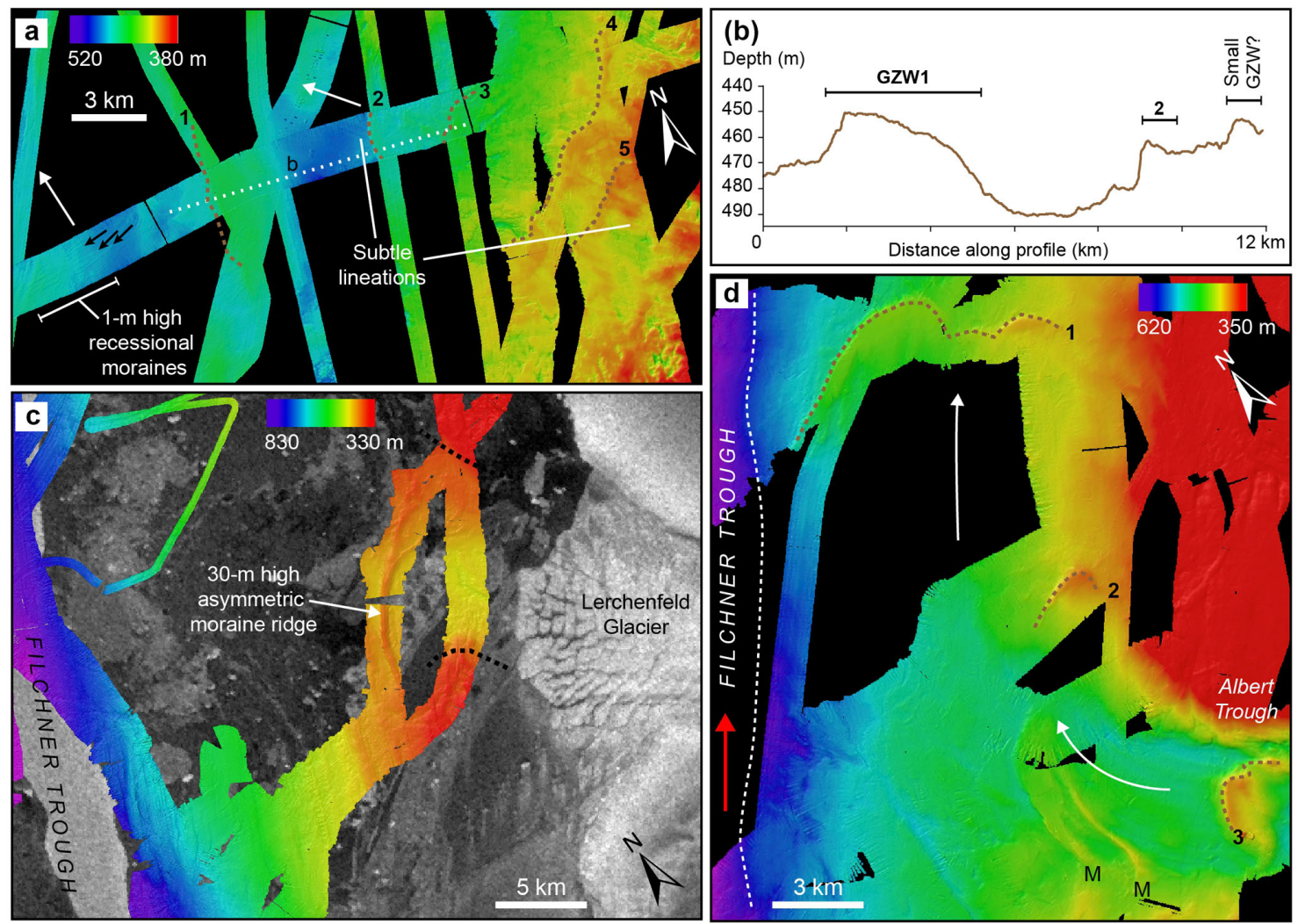

Figure 7. Detail of landform assemblages west of the Coats Land glacial troughs indicating connections to the main ice stream advance and retreat in Filchner Trough. (a) A series of five GZWs marked by numbered dashed lines and recessional moraines marked by arrows $>20 \mathrm{~km}$ north of Caird Trough with cross profile in (b); profile across three of the GZWs west of Caird Trough. The location of the profile is marked by the white dotted line in (a). (c) Landforms in Vashel Bay formed by extension of the Lerchenfeld and Schweitzer glaciers. The approximate trough margins, based on the bathymetry, are marked with black dotted lines. (d) Landforms west and north of Albert Trough showing lineations (labelled "M") trending parallel to past ice flow in Filchner Trough (red arrow) and across-flow GZWs marked by numbered dashed lines.

likely generated from glaciomarine sediments reworked by ice grounded on the crest of GZW.

A topographic high occurs to the west of the Brunt Basin (Figs. 4a, 5). Named the McDonald Bank, it forms part of a $100-400 \mathrm{~m}$ high ridge of glacial sediments with internal truncated reflectors (seismic profile 5; Elverhøi and Maisey, 1983) rising to within ca. $220 \mathrm{~m}$ of present sea level. Surface altimetry of the BIS shows that the McDonald Bank deflects the flow of the SWGT to the north and BIS to the south. Back stresses create a series of upstream concentric pressure waves in the ice shelf. This area of deformation is known as the McDonald Ice Rumples $\left(75^{\circ} 28^{\prime} \mathrm{S}, 26^{\circ} 18^{\prime} \mathrm{W}\right.$ ), which cover an area of approximately $3 \times 3 \mathrm{~km}^{2}$ (Fig. 10). Apart from the Lyddan Ice Rise (north of the SWGT, Fig. 1c), the deformation of the BIS around the McDonald Ice Rumples is the only evidence in the study area of ice being in contact with the bed beyond the grounding line. This can be attributed to differences in water depth, with the McDonald Bank being less than $220 \mathrm{~m}$ from the surface while the topographic highs formed by the GZWs in Dawson-Lambton and Albert troughs are at 380 and $450 \mathrm{~m}$, respectively (Fig. $4 \mathrm{~b}, \mathrm{c}$ ). These differences in water depth constrain the potential of these topographic highs to act as pinning points for advancing ice streams and glacier tongues.

\subsection{Chronological constraints}

The timing of ice advance and retreat is not well constrained by our data.

Mixed microfossil ages of ca. $34140 \mathrm{cal}$. yr BP (at $80 \mathrm{~cm}$ core depth) and $>43500{ }^{14} \mathrm{C} \mathrm{yr} \mathrm{BP} \mathrm{(at} 60 \mathrm{~cm}$ depth; Table 1) were found in the gravity-flow deposits sampled at the base of the GZW in Dawson-Lambton Trough (GC626, Fig. 9b). This suggests that glaciomarine sediments from Marine Isotope Stage 3 (MIS3), and predating the last ice advance, were present and being reworked during the progradation of the GZW.

A radiocarbon age of 24931 cal. yr BP (Table 1) from a calcareous microfossil in the glaciomarine sediments, immediately underlying the diamicton on the crest of the 


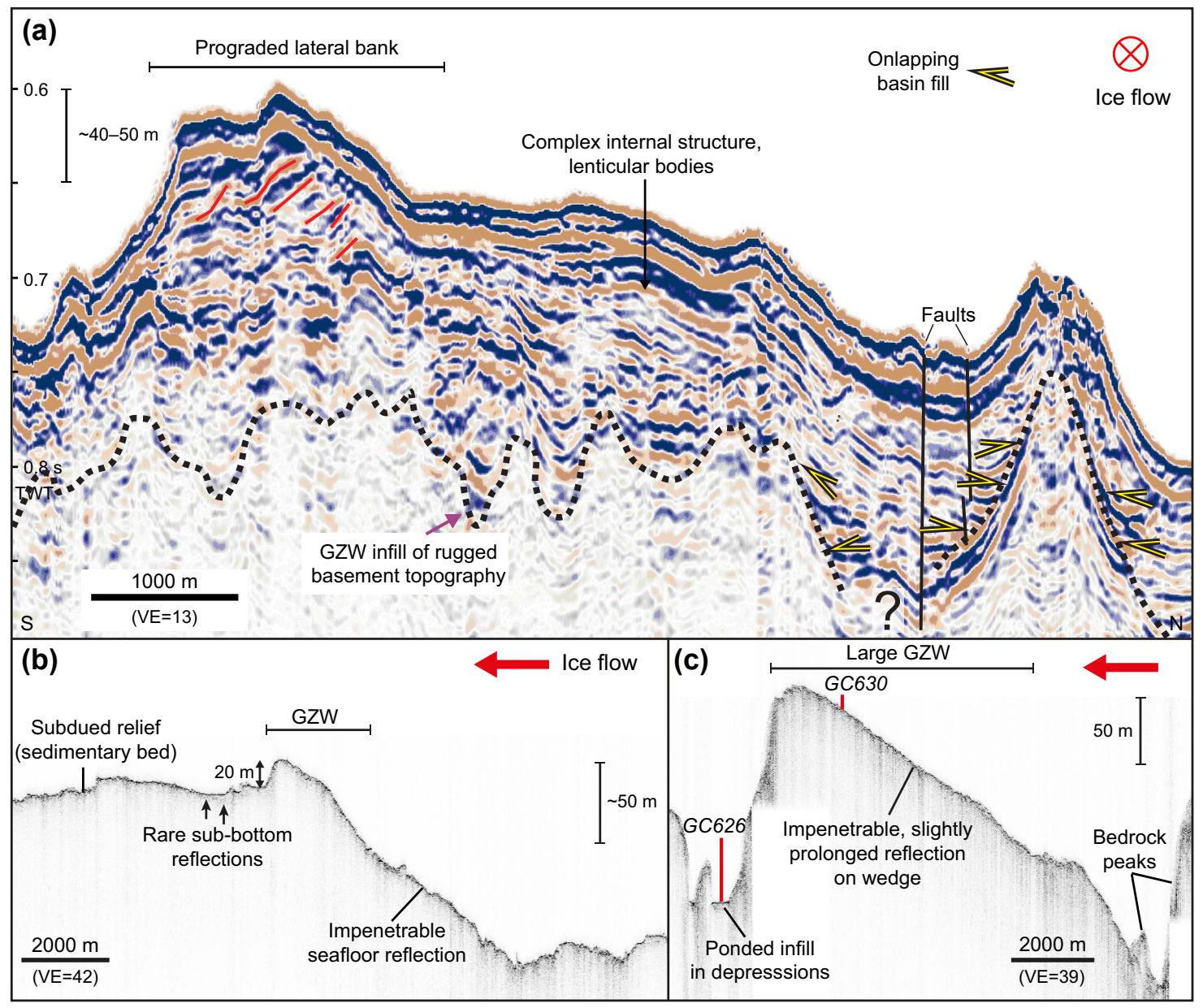

Figure 8. Seismic and sub-bottom parametric echo sounder profiles over GZWs on the Coats Land margin. (a) Seismic-reflection profile BAS101-s116 along-strike of the large GZW upstream of the deep basin in Dawson-Lambton Trough (location shown in Fig. 3a). This shows that the GZW consists of up to $80 \mathrm{~m}$ of unconsolidated stratified sediment units over a rugged bedrock surface (black dotted line). Prograding strata are indicated by red lines, together with lenticular bodies and faults. Onlapping basin fills are marked by yellow arrowheads. Thickness bar on $y$ axis calculated with 1.6-2.0 $\mathrm{km} \mathrm{s}^{-1}$. (b) TOPAS sub-bottom parametric echo sounder profile over a GZW in Albert Trough (for location see black dotted line in Fig. 3c). This shows generally impenetrable upper reflections. (c) TOPAS sub-bottom parametric echo sounder profile over the GZW in Dawson-Lambton Trough showing ponded sediment in depressions and the locations of coring sites GC630 and GC626 (for location see black dotted line in Fig. 3a). VE is the vertical exaggeration and TWT is the two-way travel time in seconds ( $y$ axis).

GZW in Dawson-Lambton Trough $(100 \mathrm{~cm}$ in GC630, Fig. 9a), provides a minimum age constraint before the onset of the last ice advance. The older microfossil age of ca. 33837 cal. yr BP is found in the overlying sandy mud at $40 \mathrm{~cm}$ core depth can be attributed to the continued reworking and progradation of MIS3 glaciomarine sediments.

In terms of ice retreat, a basal date from GC569 in the deep basin in Albert Trough (Fig. 6) gave a bulk acid-insoluble organic age of $13382 \mathrm{cal}$. yr BP (Table 1). Subtracting the 4899 yr surface age of the core yields a minimum corrected age of 8483 cal. yr BP. The presence of mixed ages (ranging from 3693 to 6550 cal. yr BP) in the diatomaceous ooze above $3.88 \mathrm{~m}$ indicates that this date must be treated with caution due to sediment mixing and/or varying contributions of reworked fossil carbon.

\section{Discussion}

Observations in the vicinity of present-day grounding lines are typically difficult to obtain in Antarctica (De Rydt and Gudmundsson, 2016). One way of addressing this is to study the bed geometry along coastlines exhibiting various stages of ice retreat. Applied here, this approach has revealed many of the features constraining the regional dynamics of the Coats Land ice margin. Below we describe what these glacial geomorphological features reveal about the ice sheet during 

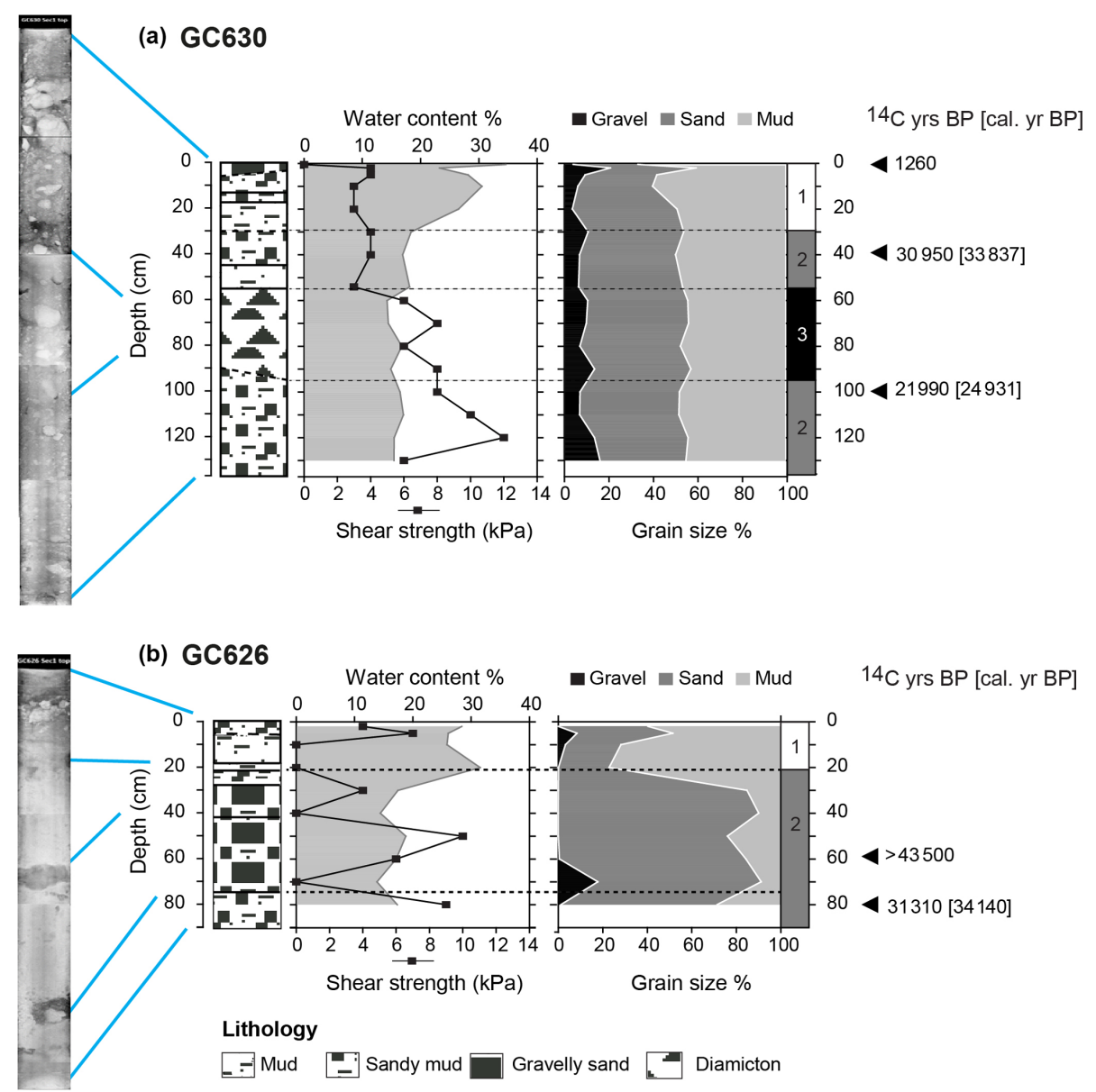

Figure 9. X-ray images, lithology, shear strength, water content and grain size analyses for sediment cores. (a) GC630 from the crest of the GZW in the Dawson-Lambton Trough. The core consists of stratified pebbly/sandy muds at its base $(137.5-90 \mathrm{~cm})$ overlain by a massive a muddy diamicton $(90-55.5 \mathrm{~cm})$ and then a sequence of gravelly sands and sandy muds $(55.5-0 \mathrm{~cm})$. Shear strength generally increases downcore, reaching a maximum of $12 \mathrm{kPa}$. (b) GC626 on the distal side of the GZW. The core consists of a sequence of a sandy mud at its base $(90-75 \mathrm{~cm})$ with dispersed foraminifera throughout, overlain by normally graded foraminifera-bearing gravel to muddy sand $(75-22 \mathrm{~cm})$. Above this $(22-0 \mathrm{~cm})$ is a homogenous sandy mud, with dispersed gravel grains in the top $5 \mathrm{~cm}$.

the last maximum ice advance, the modes of ice retreat and the influence of the bed and ice geometry on future regional ice-shelf and ice-sheet stability.

\subsection{Last maximum ice advance}

The MIS3 marine microfossils incorporated in the reworked sediments of Albert and Dawson-Lambton troughs and elsewhere in the Weddell Sea (Hillenbrand et al., 2014) suggest widespread seasonally open water before the last main ice advance. This, in addition to previous advances, has contributed to the erosion of the 450-900 deep glacial troughs and trough basins along the Coats Land ice margin. The streamlined landforms in bedrock, moraine complexes trending NNW from Albert Trough (Fig. 4c), GZWs north of Albert Trough (Fig. 7c) and the NNW-trending trough under the BIS-SWGT show that ice flow from Coats Land was redirected by the pFIS, contributing to a regional ice advance in the Filchner Trough sometime after $24931 \mathrm{cal}$.yr BP (GC630). In Filchner Trough, this ice advance has previously been dated to sometime after $11800 \mathrm{cal}$. yr BP (Arndt et al., 2017). It followed evidence of an earlier ice advance prior to $27500 \mathrm{cal}$. yr BP (Arndt et al., 2017), which was characterised by subglacial lineations and drumlins extending to within approximately $40 \mathrm{~km}$ of the shelf break (Fig. 1c) (Gales et al., 2012; Hillenbrand et al., 2014; Larter et al., 2012). Combined, the evidence suggests that streaming ice in the Coats Land troughs, together with the major ice streams feeding the pFIS (Bailey Ice Stream, Slessor and Recovery glaciers) and lower relative sea levels, may have contributed to the drawdown of the interior ice sheet. This would provide a mechanism for the minor thickening, lack of change or even thinning seen in the hinterland (Bentley et al., 2010; Hein et al., 2011; Hodgson et al., 2012; Parrenin et al., 2004; Whitehouse et al., 2012a). 


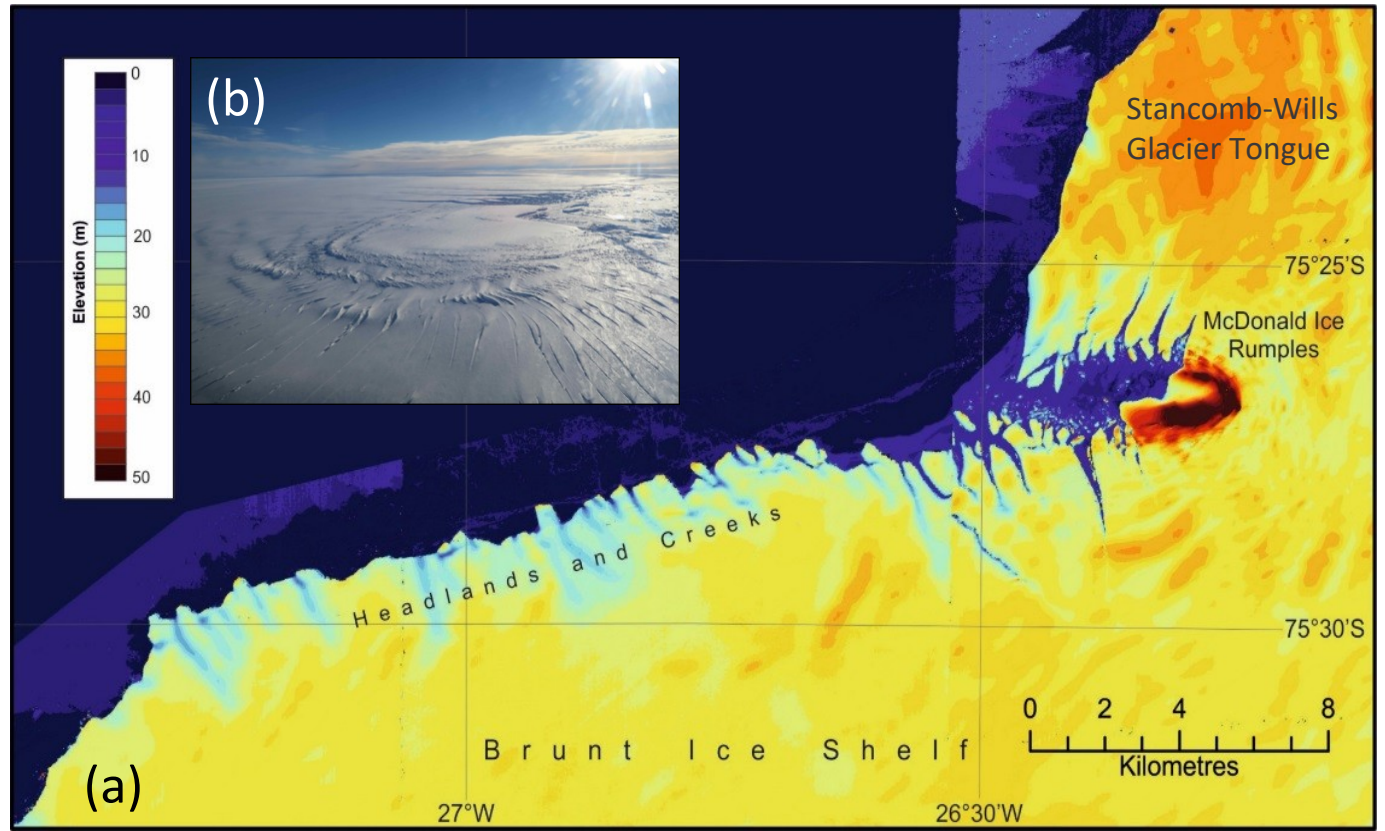

Figure 10. (a) Surface altimetry of the north-eastern part of the Brunt Ice Shelf and the McDonald Ice Rumples showing the deformation of the ice shelf where it is deflected around the McDonald Bank (Fig. 5). (b) An oblique aerial photograph of the McDonald Ice Rumples in 2017, facing NNW (credit: Jan de Rydt, BAS).

\subsection{Ice retreat}

The large volumes of glacial sediments in the Filchner Trough and downstream of the higher-velocity Coats Land glaciers have been reworked into a number of landforms that document the retreat of grounded ice. The first group of landforms includes features oriented transverse to the pFIS, the best examples being the previously described GZWs in Filchner Trough (Arndt et al., 2017; Larter et al., 2012) and beyond Albert Trough (this study, Fig. 7d). The second group of landforms is oriented transverse to the ice streams, glaciers and ice shelves discharging from Coats Land. These include the GZWs beyond Caird Trough (Fig. 7a) and Lerchenfeld Glacier (Fig. 7c), terminal moraines at the seaward end of the deep basins and at trough narrowings, and the withintrough GZWs. These landform assemblages suggest at least four phases in the ice retreat across the inner shelf.

The first phase was the southward migration of the pFIS ice front in the eastern Weddell Sea and the progressive loss of contact between the Filchner Ice Shelf and Coats Land glaciers from 12848 to $8351 \mathrm{cal}$. yr BP. The timing of this southward migration is consistent with "scenario B" of Hillenbrand et al. (2014) for regional deglaciation, with sediment age constraints from this, and other studies, tracking an approximate north-to-south migration of the Filchner Ice Shelf (Table 1). This began with core G2 off the DawsonLambton Trough at $12848 \mathrm{cal}$. yr BP, followed by core 3-6-1 off Caird Trough at 9555 cal. yr BP, core GC569 in Albert Trough at $8483 \mathrm{cal}$. yr BP (this study with the surface correc- tion applied), core G7 off the Lerchenfeld and Schweitzer glaciers at $8676 \mathrm{cal}$. yr BP and core PS1621 south of Vahsel Bay near the Filchner Ice Shelf front at $8351 \mathrm{cal}$. yr BP (all core locations in Fig. 1c). At some point during this southward migration the pFIS lifted off the bed and became an ice shelf, resulting in the preservation of subglacial lineations and drumlins in Filchner Trough (Fig. 1b; Larter et al., 2012). Landforms associated with grounded ice and quasi-stable ice-margin positions, such as GZWs, are therefore rare in the main Filchner Trough; the exceptions are one GZW landward of linear iceberg furrows on the outer shelf (Larter et al., 2012), and one stacked GZW on the outer shelf, deposited after 11800 cal. yr BP. (Arndt et al., 2017). However, chronological control and survey data are exceedingly sparse over most of the trough (as shown by Fig. 1b, c).

The southward-migrating Filchner Ice Shelf front resulted in a loss of buttressing and a shift in the orientation of the Coats Land glaciers that initiated their retreat. This second phase of grounded ice retreat was punctuated by grounding line halts at the trough narrowings (e.g. Fig. 3b and c) and topographic highs, the formation of GZWs and moraines at the seaward end of the deep basins in the troughs (e.g. Fig. 3e). The period of grounding line stability provided by the progradation of the GZWs was likely shortlived, possibly in the region of a few hundreds to thousands of years (based on estimates elsewhere: Batchelor and Dowdeswell, 2015; Dowdeswell and Fugelli, 2012; Jakobsson et al., 2012), and would have been dependent on sedi- 
ment flux rates (Graham et al., 2010; Livingstone et al., 2016) and water depth.

The third phase involved development of subglacial cavities, loss of contact with the bed and the formation of ice shelves along the Coats Land ice margin. The absence of iceberg plough marks and recessional moraines in the troughs with soft sedimentary substrates suggests that this phase of ice retreat was controlled by thinning to form ice shelves and not retreat of grounded calving ice fronts.

Based on the landform assemblages in the troughs and modern analogues around the nearby Dronning Maud Land ice margin we infer that, during the fourth phase, the newly formed ice shelves advanced to the shallower, outer parts of the troughs. Here, at least some of them would have regrounded on topographic highs and on inner trough GZWs. In the latter case, the re-grounding may have reworked at least part of the sediments comprising the GZWs - for example the prograded structures on the surface of the GZW in Dawson-Lambton Trough (Fig. 8a), and the gravelly sands and sandy muds overlaying the structureless diamicton in GC630 (Fig. 9a). However, once the ice shelves thinned to the point where mechanical contact with the bed was fully lost, the reverse-bed slope and consequent absence of further pinning points, likely resulted in their rapid retreat back towards the modern coastal grounding line where a rising bed stabilises the ice sheet. These processes, in particular the loss of contact with the bed, explain the absence of large extant ice shelves between 75.5 and $77^{\circ} \mathrm{S}$.

\subsection{Future behaviour of the ice sheet and ice shelves}

The submarine geomorphology, ice-sheet geometry, and deglacial history of the Coats Land ice margin provide constraints on the future behaviour of the ice sheet in this region.

First, it is clear that loss of the connection between the ice shelves and the bed had a threshold impact on ice-shelf stability. The geomorphological evidence suggests that current absence of ice shelves south of the BIS $\left(75.5-77^{\circ} \mathrm{S}\right)$ can be attributed to loss of contact with the bed, with the reversebed slopes (Figs. 2e, 3d) depriving retreating ice shelves of further pinning points.

This failure to reconnect with the bed is exemplified by the behaviour of the SWGT and the Dawson-Lambton Ice Stream tongues, which are essentially "failed ice shelves". Historical records show successive extensions of these glaciers over the last 100 years have been of insufficient extent or thickness to re-establish contact with the topographic highs at the distal ends of their troughs. These have included a temporary $>10 \mathrm{~km}$ long ice tongue in front of the DawsonLambton Ice Stream surveyed during the 1958 International Geophysical Year (Admiralty Charts, British Antarctic Survey Archives), and an extension, then substantial calving, of the SWGT sometime between 1915 and 1955 (Thomas, 1973). The latter shows that the SWGT remains predisposed to large-scale calving events despite potential lateral buttress- ing from the Lyddan Ice Rise (Fig. 1c) and McDonald Ice Rumples (Fig. 10).

In this context the BIS can be considered close to failure as connection with the bed is limited to a very small $(3 \times 3 \mathrm{~km})$ part of the McDonald Bank. This represents about $0.03 \%$ of the surface area of the BIS-SWGT using the $27950 \mathrm{~km}^{2}$ estimate of Humbert et al. (2009). Here the limited contact with the bed makes the ice shelf particularly vulnerable to only moderate changes in ice draught. A surge event in 1971 (Thomas, 1973) is consistent with a thinning of the ice shelf and a temporary loss of contact with the bed. As a result, iceshelf velocities accelerated from 400 to $>700 \mathrm{~m} \mathrm{a}^{-1}$ between 1968 and 1982 (Simmons and Rouse, 1984), immediately preceded by the formation of rifts upstream of the ice rumples in 1968 (Thomas, 1973). This behaviour is supported by an ice-flow model which shows that temporary loss of mechanical contact with the bed simulated for the 1971 local calving event can explain both a near-instantaneous 2-fold increase in ice velocities over a large section of the ice shelf and a subsequent decrease once contact was re-established with the McDonald Bank (Gudmundsson et al., 2016).

Second, the extant glacier tongues and ice shelves consist of ice which loses its structural integrity when flowing across the steep grounding line (King et al., 2018). For example, at the grounding lines of the Stancomb-Wills Glacier and the unnamed glaciers feeding the BIS, the marked change in surface gradient forms a "hinge zone" at the transition between the interior grounded ice and floating ice masses. This change in gradient known as the Brunt Icefalls $\left(75^{\circ} 55^{\prime} \mathrm{S}, 25^{\circ} 0^{\prime} \mathrm{W}\right.$; Fig. 5) extends for about $80 \mathrm{~km}$. Here, the ice-sheet fragments into a melange of icebergs forward of the grounding line (Anderson et al., 2014). These meteoric icebergs then "fuse" together with sea ice and with falling and drifting snow layers bridging the space between them to form a structurally heterogeneous ice shelf. Although sea ice has plastic (and therefore stabilising) properties (Holland et al., 2015), the meteoric ice units are more prone to fracture (Kulessa et al., 2014). However, observations on the BIS have shown that rifts preferentially skirt the edges of the incorporated icebergs and slow their rate of propagation when forced by the stress field to break through them (King et al., 2018). It is still not known whether the heterogeneous nature of these ice shelves will make them more or less vulnerable to break-up once detached from the bed.

A relatively stable ice-sheet configuration is reached once the calving fronts of ice streams and glaciers have retreated to the coastal grounding line. Here the bedrock rises above sea level within ca. $10 \mathrm{~km}$ from the coast, and the ice streams and glaciers calve directly into the Weddell Sea. This stable configuration is consistent with an ice-sheet model that suggests stability of the Coats Land ice margin during the last interglacial (DeConto and Pollard, 2016). 


\section{Conclusions}

Widespread open water was present in the Weddell Sea before the LGM, with MIS3 marine microfossils of 34140 cal. yr BP and $>43500{ }^{14} \mathrm{C}$ yr BP being incorporated in the sediments of Dawson-Lambton Trough and elsewhere (Hillenbrand et al., 2014).

Sometime before 24931 cal. yr BP (most likely between 34140 and 27500 cal. yr BP) and possibly sometime thereafter (most likely after 11800 cal. yr BP), Coats Land glaciers and ice streams advanced and were diverted northwards, flowing parallel with the pFIS and contributing to major ice advances in Filchner Trough. This, together with lower sea levels, may have contributed to regional drawdown of ice, in part explaining the minor thickening, lack of change or even thinning in the interior ice sheet.

Ice retreat consisted of the southward migration of the pFIS ice front and the loss of contact with the Coats Land ice streams and glaciers. This resulted in the removal of buttressing by the pFIS and a progressive north-to-south deglaciation of the Coats Land troughs between 12848 (DawsonLambton Trough) and 8351 cal. yr BP near the present Filchner Ice Shelf front. The retreat of grounded ice up the troughs was punctuated by grounding line halts at the trough narrowings and topographic highs, as well as the formation of sedimentary features such as GZWs and moraines at the seaward end of the deep basins in the troughs.

Loss of ice contact with the bed formed ice shelves, and an absence of iceberg plough marks suggests that this was controlled by thinning and not by calving. The advance of the ice shelves to the shallower, outer parts of the troughs may have resulted in their re-grounding on some of the withintrough GZWs and topographic highs.

Subsequent retreat of these ice shelves was governed by the interaction between the ice and the bed. Once the ice thinned to the point where mechanical contact with the bed was fully lost, the reverse-bed slope and consequent absence of further pinning points in the troughs resulted in their rapid retreat to the present-day grounding line. These processes explain the absence of large extant ice shelves between the BIS and Filchner Ice Shelf.

The fact that ice shelves are absent along much of the Coats Land ice margin suggests that loss of buttressing has been more important than atmospheric or ocean temperatures in determining where ice shelves have survived in this region. At the BIS-SWGT, contact with the bed at the McDonald Ice Rumples is therefore critical to maintaining the ice shelf in the future.

Data availability. The datasets used in this paper are available at the NERC UK Polar Data Centre (https://www.bas.ac.uk/data/ uk-pdc/, last access: 18 July 2018).
Author contributions. The study was conceived and written by DAH and KH. DAH, RL, JAS, CD H, CA, VP and AGCG took part in JR244 collecting and processing the geophysical data and sediment cores. Additional datasets were assembled by PF (BIS altimetry and sub-ice shelf topographic compilation), AMS (Seismic data under BIS-SWGT), JMS (editing multibeam data), $\mathrm{CH}$ (processing seismic profile of GZW in Dawson-Lambton Trough), JEA, and BD (multibeam data from Alfred Wegener Institute). All authors commented on the manuscript.

Competing interests. The authors declare that they have no conflict of interest.

Acknowledgements. This study was supported by the captain, officers and ship's crew of RRS James Clark Ross cruise JR244 as well as other members of the shipboard scientific party, including Jenny A. Gales, Svein Østerhus, Mark O. Preston, Mark W. Robinson, Jeremy P. Robst, Marcel Ruhnau, Daniela Sprenk and Jonas Wagner. Jan-Erik Arndt was funded by the Deutsche Forschungsgemeinschaft (DFG, German Research Foundation) grant AR 1087/1-1. This research contributes to NERC grant NE/K003674/1 "Reducing the uncertainty in estimates of the sea level contribution from the westernmost part of the East Antarctic Ice Sheet". The editor and reviewers are thanked for their constructive suggestions that improved the manuscript.

Edited by: Chris R. Stokes

Reviewed by: Brian J. Todd and Andrew Hein

\section{References}

Alley, R. B., Blankenship, D. D., Rooney, S. T., and Bentley, C. R.: Sedimentation beneath ice shelves - the view from ice stream B, Mar. Geol., 85, 101-120, 1989.

Anderson, R., Jones, D. H., and Gudmundsson, G. H.: Halley Research Station, Antarctica: calving risks and monitoring strategies, Nat. Hazards Earth Syst. Sci., 14, 917-927, https://doi.org/10.5194/nhess-14-917-2014, 2014.

Arndt, J. E., Schenke, H. W., Jakobsson, M., Nitsche, F. O., Buys, G., Goleby, B., Rebesco, M., Bohoyo, F., Hong, J., Black, J., Greku, R., Udintsev, G., Barrios, F., Reynoso-Peralta, W., Taisei, M., and Wigley, R.: The International Bathymetric Chart of the Southern Ocean (IBCSO) Version 1.0 - A new bathymetric compilation covering circum-Antarctic waters, Geophys. Res. Lett., 40, 3111-3117, 2013.

Arndt, J. E., Hillenbrand, C. D., Grobe, H., Kuhn, G., and Wacker, L.: Evidence for a dynamic grounding-line in outer Filchner Trough, Antarctica, until the early Holocene, Geology, 45, 10351038, https://doi.org/10.1130/G39398.1, 2017.

Bamber, J. L., Ferraccioli, F., Joughin, I., Shepherd, T., Rippin, D. M., Siegert, M. J., and Vaughan, D. G.: East Antarctic ice stream tributary underlain by major sedimentary basin, Geology, 34, 3336, 2006.

Bassett, S. E., Milne, G. A., Bentley, M. J., and Huybrechts, P.: Modelling Antarctic sea-level data to explore the possibility of a 
dominant Antarctic contribution to meltwater pulse IA, Quaternary Sci. Rev., 26, 2113-2127, 2007.

Batchelor, C. L. and Dowdeswell, J. A.: Ice-sheet groundingzone wedges (GZWs) on high-latitude continental margins, Mar. Geol., 363, 65-92, 2015.

Bentley, M. J., Fogwill, C. J., Le Brocq, A. M., Hubbard, A. L., Sugden, D. E., Dunai, T., and Freeman, S. P. H. T.: Deglacial history of the West Antarctic Ice Sheet in the Weddell Sea embayment: constraints on past ice volume change, Geology, 38, 411-414, 2010.

De Rydt, J. and Gudmundsson, G. H.: Coupled ice shelfocean modeling and complex grounding line retreat from a seabed ridge, J. Geophys. Res.-Earth, 121, 865-880, https://doi.org/10.1002/2015JF003791, 2016.

DeConto, R. M. and Pollard, D.: Contribution of Antarctica to past and future sea-level rise, Nature, 531, 591-597, 2016.

Dowdeswell, J. A. and Fugelli, E. M. G.: The seismic architecture and geometry of grounding-zone wedges formed at the marine margins of past ice sheets, Geol. Soc. Am. Bull., 124, 1750 1761, https://doi.org/10.1130/b30628.1, 2012.

Elverhøi, A. and Maisey, G.: Glacial erosion and morphology of the eastern and southeastern Weddell Sea shelf, in: Fourth International Symposium Antarctic Earth Science, edited by: Oliver, R. L., James, P. R., and Jago, J. B., Aust. Acad. of Sci., Adelaide, South Australia, 1983.

Fretwell, P., Pritchard, H. D., Vaughan, D. G., Bamber, J. L., Barrand, N. E., Bell, R., Bianchi, C., Bingham, R. G., Blankenship, D. D., Casassa, G., Catania, G., Callens, D., Conway, H., Cook, A. J., Corr, H. F. J., Damaske, D., Damm, V., Ferraccioli, F., Forsberg, R., Fujita, S., Gim, Y., Gogineni, P., Griggs, J. A., Hindmarsh, R. C. A., Holmlund, P., Holt, J. W., Jacobel, R. W., Jenkins, A., Jokat, W., Jordan, T., King, E. C., Kohler, J., Krabill, W., Riger-Kusk, M., Langley, K. A., Leitchenkov, G., Leuschen, C., Luyendyk, B. P., Matsuoka, K., Mouginot, J., Nitsche, F. O., Nogi, Y., Nost, O. A., Popov, S. V., Rignot, E., Rippin, D. M., Rivera, A., Roberts, J., Ross, N., Siegert, M. J., Smith, A. M., Steinhage, D., Studinger, M., Sun, B., Tinto, B. K., Welch, B. C., Wilson, D., Young, D. A., Xiangbin, C., and Zirizzotti, A.: Bedmap2: improved ice bed, surface and thickness datasets for Antarctica, The Cryosphere, 7, 375-393, https://doi.org/10.5194/tc-7-375-2013, 2013.

Gales, J. A., Larter, R. D., Mitchell, N. C., Hillenbrand, C. D., Østerhus, S., and Shoosmith, D. R.: Southern Weddell Sea shelf edge geomorphology: Implications for gully formation by the overflow of high-salinity water, J. Geophys. Res.-Earth, 117, F04021, https://doi.org/10.1029/2012JF002357, 2012.

Graham, A. G. C., Larter, R. D., Gohl, K., Hillenbrand, C. D., Smith, J. A., and Kuhn, G.: Bedform signature of a West Antarctic palaeo-ice stream reveals a multi-temporal record of flow and substrate control, Quaternary Sci. Rev., 28, 2774-2793, 2009.

Graham, A. G. C., Larter, R. D., Gohl, K., Dowdeswell, J. A., Hillenbrand, C. D., Smith, J. A., Evans, J., Kuhn, G., and Deen, T. J.: Flow and retreat of the Late Quaternary Pine Island-Thwaites palaeo-ice stream, West Antarctica, J. Geophys. Res.-Earth, 115, F03025, https://doi.org/10.1029/2009JF001482, 2010.

Gudmundsson, G. H., De Rydt, J., and Nagler, T.: Five decades of strong temporal variability in the flow of the Brunt Ice Shelf, Antarctica, J. Glaciol., 63, 164-175, 2016.
Hättestrand, C. and Johansen, N.: Supraglacial moraines in Scharffenbergbotnen, Heimefrontfjella, Dronning Maud Land, Antarctica - significance for reconstructing former blue ice areas, Antarct. Sci., 17, 225-236, 2005.

Hein, A. S., Fogwill, C. J., Sugden, D. E., and Xu, S.: Glacial/interglacial ice-stream stability in the Weddell Sea embayment, Antarctica, Earth Planet. Sc. Lett., 307, 211-221, 2011.

Hein, A. S., Fogwill, C. J., Sugden, D. E., and Xu, S.: Geological scatter of cosmogenic-nuclide exposure ages in the Shackleton Range, Antarctica: Implications for glacial history, Quat. Geochronol., 19, 52-66, 2014.

Hillenbrand, C. D., Melles, M., Kuhn, G., and Larter, R. D.: Marine geological constraints for the grounding-line position of the Antarctic Ice Sheet on the southern Weddell Sea shelf at the Last Glacial Maximum, Quaternary Sci. Rev., 32, 25-47, 2012.

Hillenbrand, C. D., Bentley, M. J., Stolldorf, T., Hein, A. S., Kuhn, G., Graham, A. C. G., Fogwill, C. J., Kristoffersen, Y., Smith, J. A., Anderson, J. B., Larter, R. D., Melles, M., Hodgson, D. A., Mulvaney, R., and Sugden, D. E.: Reconstruction of changes in the Weddell Sea sector of the Antarctic Ice Sheet since the Last Glacial Maximum, Quaternary Sci. Rev., 100, 111-136, 2014.

Hodgson, D. A., Bentley, M. J., Schnabel, C., Cziferszky, A., Convey, P., and $\mathrm{Xu}, \mathrm{S} .:$ Glacial geomorphology and cosmogenic ${ }^{10} \mathrm{Be}$ and ${ }^{26} \mathrm{Al}$ exposure ages in the northern Dufek Massif, Weddell Sea embayment, Antarctica, Antarct. Sci., 24, 377-394, https://doi.org/10.1017/S0954102012000016, 2012.

Holland, P. R., Brisbourne, A., Corr, H. F. J., McGrath, D., Purdon, K., Paden, J., Fricker, H. A., Paolo, F. S., and Fleming, A. H.: Oceanic and atmospheric forcing of Larsen C Ice-Shelf thinning, The Cryosphere, 9, 1005-1024, https://doi.org/10.5194/tc9-1005-2015, 2015.

Hübscher, C. and Gohl, K.: Reflection/Refraction Seismology, Encyclopedia of Marine Geosciences,https://doi.org/10.1007/98794-007-6644-0_128-1, 2014.

Humbert, A., Kleiner, T., Mohrholz, C.-O., Oelke, C., Greve, R., and Lange, M. R.: A comparative modeling study of the Brunt Ice Shelf/Stancomb-Wills Ice Tongue system, East Antarctica, J. Glaciol., 55, 53-65, 2009.

Huybrechts, P., Rybak, O., Pattyn, F., Ruth, U., and Steinhage, D.: Ice thinning, upstream advection, and non-climatic biases for the upper $89 \%$ of the EDML ice core from a nested model of the Antarctic ice sheet, Clim. Past, 3, 577-589, https://doi.org/10.5194/cp-3-577-2007, 2007.

Jakobsson, M., Anderson, J. B., Nitsche, F. O., Gyllencreutz, R., Kirshner, A. E., Kirchner, N., O'Regan, M., Mohammad, R., and Eriksson, B.: Ice sheet retreat dynamics inferred from glacial morphology of the central Pine Island Bay Trough, West Antarctica, Quaternary Sci. Rev., 38, 1-10, 2012.

King, E. C., Hindmarsh, R. C. A., and Stokes, C. R.: Formation of mega-scale glacial lineations observed beneath a West Antarctic ice stream, Nat. Geosci., 2, 585-588, 2009.

King, E. C., De Rydt, J., and Gudmundsson, G. H.: The internal structure of the Brunt Ice Shelf from ice-penetrating radar analysis and implications for ice shelf fracture, The Cryosphere Discuss., https://doi.org/10.5194/tc-2018-13, in review, 2018.

Kulessa, B., Jansen, D., Luckman, A. J., King, E. C., and Sammonds, P. R.: Marine ice regulates the future stability of a large Antarctic ice shelf, Nat. Comm., 5, 3707, https://doi.org/10.1038/ncomms4707, 2014. 
Larter, R. D., Graham, A. G. C., Hillenbrand, C.-D., Smith, J. A., and Gales, J. A.: Late Quaternary grounded ice extent in the Filchner Trough, Weddell Sea, Antarctica: new marine geophysical evidence, Quaternary Sci. Rev., 53, 111-122, 2012.

Le Brocq, A. M., Bentley, M. J., Hubbard, A., Fogwill, C. J., Sugden, D. E., and Whitehouse, P. L.: Reconstructing the Last Glacial Maximum ice sheet in the Weddell Sea embayment, Antarctica, using numerical modelling constrained by field evidence, Quaternary Sci. Rev., 30, 2422-2432, 2011.

Livingstone, S. J., Storrar, R. D., Hillier, J. K., Stokes, C. R., Clark, C. D., and Tarasov, L.: An ice-sheet scale comparison of eskers with modelled subglacial drainage routes, Geomorphology, 246, 104-112, 2015.

Livingstone, S. J., Ó Cofaigh, C., Hogan, K. A., and Dowdeswell, J. A.: Submarine glacial-landform distribution along an Antarctic Peninsula palaeo-ice stream: a shelf-slope transect through the Marguerite Trough system (66-70 ${ }^{\circ}$ S), Geological Society, London, Memoirs, 46, 485-492, 2016.

Nitsche, F. O., Gohl, K., Larter, R. D., Hillenbrand, C.-D., Kuhn, G., Smith, J. A., Jacobs, S., Anderson, J. B., and Jakobsson, M.: Paleo ice flow and subglacial meltwater dynamics in Pine Island Bay, West Antarctica, The Cryosphere, 7, 249-262, https://doi.org/10.5194/tc-7-249-2013, 2013.

Ó Cofaigh, C., Dowdeswell, J. A., Allen, C. S., Hiemstra, J. F., Pudsey, C. J., Evans, J., and Evans, D. J. A.: Flow dynamics and till genesis associated with a marine-based Antarctic palaeo-ice stream, Quaternary Sci. Rev., 24, 709-740, 2005.

Ottesen, D., Dowdeswell, J. A., and Rise, L.: Submarine landforms and the reconstruction of fast-flowing ice streams within a large Quaternary ice sheet: The 2500-km-long Norwegian-Svalbard margin $\left(57^{\circ}-80^{\circ} \mathrm{N}\right)$, GSA Bulletin, 117, 1033-1050, 2005.

Parrenin, F., Rémy, F., Ritz, C., Siegert, M. J., and Jouzel, J.: New modeling of the Vostok ice flow line and implication for the glaciological chronology of the Vostok ice core, J. Geophys. Res.-Atmos., 109, D20102, https://doi.org/10.1029/2004JD004561, 2004.

Reimer, P. J., Bard, E., Bayliss, A., Beck, J. W., Blackwell, P. G., Ramsey, C. B., Buck, C. E., Cheng, H., Edwards, R. L., Friedrich, M., Grootes, P. M., Guilderson, T. P., Haflidason, H., Hajdas, I., Hatté, C., Heaton, T. J., Hoffmann, D. L., Hogg, A. G., Hughen, K. A., Kaiser, K. F., Kromer, B., Manning, S. W., Niu, M., Reimer, R. W., Richards, D. A., Scott, E. M., Southon, J. R., Staff, R. A., Turney, C. S. M., and van der Plicht, J.: IntCal13 and Marine13 Radiocarbon Age Calibration Curves 0-50,000 Years cal BP, Radiocarbon, 55, 1869-1887, 2013.
Rignot, E., Mouginot, J., and Scheuchl, B.: Ice Flow of the Antarctic Ice Sheet, Science, 333, 1427-1430, 2011.

Rippin, D. M., Siegert, M. J., Bamber, J. L., Vaughan, D. G., and Corr, H. F. J.: Switch-off of a major enhanced ice flow unit in East Antarctica, Geophys. Res. Lett., 33, L15501, https://doi.org/10.1029/2006GL026648, 2006.

Ross, N., Bingham, R. G., Corr, H. F. J., Ferraccioli, F., Jordan, T. A., Le Brocq, A., Rippin, D. M., Young, D., Blankenship, D. D., and Siegert, M. J.: Steep reverse bed slope at the grounding line of the Weddell Sea sector in West Antarctica, Nat. Geosci., 5, 393-396, 2012.

Simmons, D. A. and Rouse, J. R.: Accelerating Flow of the Brunt Ice Shelf, Antarctica, J. Glaciol., 30, 377-380, 1984.

Smith, J. A., Hillenbrand, C.-D., Kuhn, G., Larter, R., Graham, A. G. C., Ehrmann, W., Moreton, S. G., and Forwick, M.: Deglacial history of the West Antarctic Ice Sheet in the western Amundsen Sea Embayment, Quaternary Sci. Rev., 30, 488-505, 2011.

Stolldorf, T., Schenke, H. W., and Anderson, J. B.: LGM ice sheet extent in the Weddell Sea: Evidence for diachronous behavior of Antarctic Ice Sheets, Quaternary Sci. Rev., 48, 20-31, 2012.

Thomas, R. H.: The dynamics of the Brunt Ice Shelf, Coats Land, Antarctica British Antarctic Survey Sci. Rep.-UK, 79, 1-47, 1973.

Thor, G. and Low, M.: The persistence of the snow petrel (Pagodroma nivea) in Dronning Maud Land (Antarctica) for over 37,000 years, Polar Biol., 34, 609-613, 2010.

Whitehouse, P. L., Bentley, M. J., and Le Brocq, A. M.: A deglacial model for Antarctica: geological constraints and glaciological modelling as a basis for a new model of Antarctic glacial isostatic adjustment, Quaternary Sci. Rev., 32, 1-24, 2012a.

Whitehouse, P. L., Bentley, M. J., Milne, G. A., King, M. A., and Thomas, I. D.: A new glacial isostatic model for Antarctica: calibrated and tested using observations of relative sea-level change and present-day uplift rates, Geophys. J. Int., 190, 1464-1482, $2012 b$.

Whitehouse, P. L., Bentley, M. J., Vieli, A., Jamieson, S. S. R., Hein, A. S., and Sugden, D. E.: Controls on Last Glacial Maximum ice extent in the Weddell Sea embayment, Antarctica, J. Geophys. Res.-Earth, 122, 371-397, 2017.

Zwally, H. J., Giovinetto, M. B., Beckley, M. A., and Saba, J. L.: Antarctic and Greenland Drainage Systems, GSFC Cryospheric Sciences Laboratory, available at: http://icesat4.gsfc.nasa.gov/ cryo_data/ant_grn_drainage_systems.php, last access: 2012. 